This PDF is a selection from an out-of-print volume from the National Bureau of Economic Research

Volume Title: Problems of Capital Formation: Concepts, Measurement, and Controlling Factors

Volume Author/Editor: Conference on Research in Income and Wealth

Volume Publisher: NBER

Volume ISBN: 0-870-14175-9

Volume URL: http://www.nber.org/books/unkn57-1

Publication Date: 1957

Chapter Title: Capital Formation in Canada

Chapter Author: Kenneth Buckley

Chapter URL: http://www.nber.org/chapters/c5581

Chapter pages in book: (p. 91 - 145) 


\title{
CAPITAL FORMATION IN CANADA
}

\author{
Kenneth Buckley \\ University of Saskatchewan
}

Official estimates of capital formation in Canada have been made for the period from 1926 to the present. Since descriptions of these have been published, only a brief account of their development is given here. The main interest in this paper is in estimates of capital formation from 1900 to 1930 and the relation of these to the official estimates. Following an account of the development of the official series, estimates for the earlier period are presented with a summary of procedures followed in their derivation. ${ }^{1}$ These estimates are then compared with the official estimates to establish procedures to link the two series. Major difficulties encountered in establishing the trend and pattern of capital formation in Canada are reviewed and various limitations of the estimates are indicated in the course of the discussion.

\section{Official Estimates of Capital Formation, 1926-1952}

\section{Current Estimates}

An annual survey of business establishments and government agencies and departments is the chief method employed to determine the current level and pattern of new investment and repair and maintenance expenditures for structures and machinery and equipment. Annual outlays are obtained by type, by industry, by province and for "greater cities."2 A survey of limited coverage was started in 1941 by the Dominion Bureau of Statistics and extended after 1945, when a companion survey of investment intentions was undertaken. ${ }^{3}$ The coverage of the capital survey is

\footnotetext{
'For a full account of the procedures see Kenneth Buckley, Capital Formation in Canada, 1896-1930, University of Toron to Press, 1955.

'The annual data have also been distributed on a quarterly basis, beginning with 1946, with a break-down of new investment and repair expenditures for housing, other construction, and machinery and equipment. For the methods employed see Private and Public Investment in Canada, 1926-1951, Dept. of Trade and Commerce, 1951, pp. 217-218 (hereafter referred to as P.P.I.). This report was prepared under the direction of O. J. Firestone.

A brief description of definitions and methods employed in the surveys may be found in Private and Public Investment in Canada, Outlook 1951 (an annual publication of the Dept. of Trade and Commerce).
} 


\section{CAPITAL FORMATION IN CANADA}

high. The most recent survey (Outlook, 1953) accounted for 72 per cent of the final estimate of new investment and, after adjustment to full coverage for the sectors surveyed, for 85 per cent of the total. New investment and repair and maintenance expenditures for other sectors, including agriculture, fishing, and several service industries in which the typical production unit was small, were estimated by indirect methods.

First Series, 1926-1941: Public lnvestment and Capital Formation

A study of public and private investment in Canada for the period 1926-1941 was prepared for the Dominion-Provincial Conference on Reconstruction in 1945. " In this study gross domestic capital formation was defined as "the gross addition to all finished durable physical commodities in the hands of producers, gross residential construction and the net changes in stocks in the hands of producers"; and gross investment. as "gross domestic capital formation plus the net balance on international account" (page 11). Durable physical commodities were defined in the following terms:

"(1) All fixed durable property whether in the hands of individuals or governments.

(a) All property used for business purposes

(b) All residential property

(2) Machinery and equipment in the hands of producers, including governments" (page 10).

Expenditures by governments on conservation and development of natural resources were included in the estimates along with public and private outlays on structures and producers' machinery and equipment. Private expenditures related to resource development, e.g. exploration by mining companies and clearing and preparation of agricultural lands, were not included because no satisfactory means were available to measure them.

Two general methods were used to estimate gross investment in durable physical assets: the flow of commodities or supply method and direct estimates by user categories.

4 Public Investment and Capital Formation, A Study of Public and Private Investment Outlay, Canada, 1926-1941, Ottawa, King's Printer, 1945 (hereafter referred to as P.I.C.F.). The study was prepared under the direction of 0 . J. Firestone and M. C. Urquhart.

"In this context use of the term "direct" does not imply that users or their accounts were consulted directly, although this was often the case. A direct estimate is one made for a specific category; the data used may be directly or indirectly related to the value required. 
Direct estimates were made of new and repair construction, with a breakdown between building and engineering construction, for most of the major categories. These estimates covered virtually all engineering construction. Construction outlays of the remaining categories were obtained indirectly by deducting in each year the direct building construction estimates from an estimate of total building construction. The residual covered building construction in manufacturing, trade, finance, and some other minor sectors.

Total building construction was estimated by applying an index of the annual flow of building construction materials, excluding those used on farms, to the value of materials used in nonfarm building construction in 1941 to secure the values of materials used in each year, and raising these values to totals by applying ratios of the value of materials used to the value of building construction performed. The ratios were derived from the Census of Construction. ${ }^{\circ}$ The annual totals were distributed to new and repair construction with ratios from the same source. The benchmark estimate was made by adding estimates for several types of building construction not covered by the 1941 census to the value of building construction reported in this census. ${ }^{7}$

Estimates of expenditures on machinery and equipment were made by the supply method and from records of sales for vehicles and farm machinery. Flows of the various classes of machinery and equipment at producers' prices were determined from annual production and trade records and adjusted to final prices by additions for freight, import and sales taxes, commissions, and trade margins. The inventory adjustments were incomplete and nothing was added for installation costs.

Parts were segregated in the initial tabulations of import and export trade totals, but were included in production totals and later segregated by applying ratios derived from independent sources. Only some of these parts series were used in securing the final totals for repair and maintenance since several major

- This census has been taken since 1934 and is published annually by the Dominion Bureau of Statistics under the title, The Construction Industry in Canada.

7 The annual flow of building materials was not raised directly to secure the desired estimates in view of the difficulty of eliminating all unfinished materials, but it was assumed that since the method of obtaining the flow was consistent, the proportion of these to the total would not vary substantially. No allowance was made in the building materials series for variations in freight and trade margins. 
repair series had been estimated directly. The parts series used were not raised to include the labor cost of repair work.

Year-end book values of business inventories as well as quantities of grain and livestock and the required price records were available in either records or estimates of the Dominion Bureau of Statistics. ${ }^{B}$ A major difficulty in estimating the value of the physical change in business inventories was lack of information on inventory accounting practices among Canadian producers. It was assumed that book values were the lower of cost or market price (replacement cost); and adjustments from cost to market price were made, when required, on the assumption that cost reflected prices that had prevailed one inventory turnover period before December 31. Wholesale price indexes, weighted by production, were used to effect revaluations and deflations in each inventory class except retail trade, where a retail price index was used.

The final component of gross investment, the net balance of international transactions on current account, was obtained from the balance of payments statistics of DBS. It was unnecessary to include an item for changes in monetary gold stocks since current gold production was treated as an export and monetary gold movements as capital transactions. Since foreign investment has played a very large part in Canadian development, the use of the term "capital formation" was restricted to additions to the stock of physical capital within the country and the term "investment" applied to the sum of (domestic) capital formation and the net change in international claims.

The study achieved most of its expressed objectives and its more important limitations were left for subsequent research. The estimates of additions to durable physical assets were gross of replacements. It did not appear feasible, with the data available, to attempt to measure capital consumption nor to express the estimates in constant dollars. Finally the distribution between capital and repair was not made on a uniform basis. In the bulk of the construction estimates the distribution of totals to new and repair construction reflected accounting practices implicit in the sources used. Where these practices were not reasonably satisfactory, e.g. in the railway repair and maintenance accounts, replacement items were segregated. In other series, e.g. the machinery and equipment series derived by the supply method and in government

- Hereafter referred to as DBS. 
construction, economic criteria were applied and probably more was apportioned to capital than accounting procedures would allow.

\section{Revision: Private and Public lnvestment} in Canada, 1926-1951

A revision of the historical series in P.I.C.F. appeared in a comprehensive report on public and private investment published by the Department of Trade and Commerce in 1951.9 This report dealt only with the durable components of gross investment. It presented revisions and refinements of the earlier estimates of investment in durable physical assets from 1926 to 1941 . These were linked with the current estimates derived from the capital surveys of DBS.

With the exception of the housing series, which was completely revised, the direct estimates of the earlier study appeared unchanged or with minor revisions. New estimates were made of new and repair investment for the sectors treated as a residual in P.I.C.F. With this development, the final totals of new and repair investment were sums of direct estimates; the earlier totals for building construction and the flow of producers' durable goods were dropped.

The adjustment for capital charged to current expenses was made in P.P.I. on a consistent basis, and the distinction between new and repair investment was more uniform, conceptually. There was still no attempt to measure capital consumption, but the components of gross investment were expressed in constant as well as current dollars. In addition the report assembled and presented, in detail, current estimates from 1941 to 1951 based on the capital surveys.

The residual group in P.I.C.F. included fishing, manufacturing, construction, a number of minor utilities, wholesale and retail trade, finance, commercial services, and churches, universities, and private hospitals. For the purpose of this paper the estimates for these industries in P.P.I. may be grouped according to the two general methods used in their derivation. The bulk of the new direct estimates, which formed a significant fraction of the final totals of new investment and repair expenditures, was based upon a corporation sample study for manufacturing, construction, wholesale trade, retail trade, finance (excluding banks), and commercial services. The sample data were drawn from the returns of corporations reporting, for taxation purposes, to the Federal Department

P.P.P.I. 


\section{CAPITAL FORMATION IN CANADA}

of National Revenue from 1926 to 1946 . The estimates derived from these data are considered in section 3 below. Investment and repair expenditures for the other industries (fishing and the minor utilities) and the private institutions covered indirectly in P.I.C.F. were small relative to final totals. In general they were derived in P.P.I. by applying more or less satisfactory indexes of trend to capital survey bench-marks, usually for one component of new investment in a postwar year, and obtaining the other component of new, and the repair components, by imposing the average patterns reflected in the postwar estimates.

\section{The lnvestment Component in the National Accounts}

In the national accounts gross domestic investment included expenditures for new construction and new machinery and equipment, mining exploration and development costs, and changes in inventories of private and government business enterprises and of private noncommercial institutions. The durable components of gross domestic investment were obtained by deducting from total private and public investment in durable physical assets, as estimated in P.P.I., direct government outlays indicated in the same source. (Direct government investment included investment by government departments, federal and provincial hospitals, municipal schools, and in recent years a small amount of housing.)

Inventories held directly by governments were segregated in the basic inventory data. The estimates of investment in inventories were a mixture of two concepts: investment in farm inventories and in grain in commercial channels was calculated as the value of the physical change; investment in other business inventories, including those held by government-owned enterprises, was estimated as the change in book values of inventories during the year. ${ }^{10}$

${ }^{10}$ This mixed method was a temporary expedient. The DBS prepared the original estimates of inventory investment in P.I.C.F., but preferred not to incorporate them in the national accounts owing to several unsatisfactory elements in their derivation. Since 1945 the estimates required to fill gaps in the records of trade and miscellaneous inventories have been improved on the basis of new information, and a study of inventory accounting methods has been undertaken. The problem of appropriately weighted index numbers is currently under review. It is probable that the results of this research will be incorporated in the forthcoming final revision of the accounts for years prior to 1951. Estimates of the value of the change in business inventories, as most recently revised, can be determined from the published accounts. The inventory revaluation item for the period 1926 to the present is shown in the calculation of implicit deflators for the gross national expenditure (cf. Table 4 in National Accounts, Income and Expenditure, 1926-1950, Ottawa, DBS, 1951; and in... 1949-1952, 1953). 
Gross investment was the sum of gross domestic investment and foreign investment. The latter item was measured by the net balance of current transactions in goods and services from the international balance of payments accounts. No attempt was made to segregate the net changes in publicly and privately held stocks of international claims.

An allowance for capital consumption based on current accounting allowances for depreciation, obsolescence, and amortization was used in the national accounts to arrive at the gross national product. Capital charged to current expenses, the claim portion of insurance against fire and other property losses and of business insurance against financial loss, and bad debt allowances were included in the same item. Depreciation of capital assets held directly by governments was not included in the depreciation estimates in view of the treatment of direct government investment in the expenditure accounts.

\section{Estimates of Capital Formation, 1900-1930}

\section{Conceptual Relation to Official Estimates}

The concepts of P.I.C.F. were followed as closely as possible in the estimates of capital formation from 1900 to 1930 . The one difference in concept arose with the exclusion of direct government expenditures on resource development when they did not involve construction and machinery and equipment. The excluded items were small, accounting for $\$ 2$ million of the $\$ 1,085$ million of new investment in 1926."11

These estimates were also consistent conceptually with the estimates of P.P.I. This more recent study followed and more fully realized the conceptual framework established in P.I.C.F. P.I.C.F., for example, did not include the cost of mining exploration and development while P.P.I. apparently included a small amount for these costs. Of greater practical significance were the additions in P.P.I. of labor costs in the estimates of farm construction, previously limited to materials used, and provision for full coverage of labor costs in the repair and maintenance estimates. Other additions were made but these presumably represented corrections of errors in the earlier estimates and are considered in section 3 below.

1P.P.I., Table 9, p. 149. 


\section{Procedures}

Construction. The year 1921 was used as a bench-mark because it was the only year in the period covered when both a decennial census and a construction census were taken. The decennial census data on the construction labor force were used to inflate the value of construction reported to the construction census.

The supply method, adapted by P.I.C.F. from studies of the National Bureau of Economic Research, was used to determine the annual flow of construction materials from 1900 to 1930. Some minor changes were made in the commodity classification set up by the authors of P.I.C.F. The estimates of the annual flow of construction materials are shown in Table A-I in the appendix.

An index of the annual flow of construction materials was applied to the value of materials used in the bench-mark year to determine the value of the material component in each year. The value of construction in each year was then estimated on the basis of available data on the relationships between the material component, the labor component, and other costs included in total construction.

Finally the annual values of construction were summed for each quinquennium and the five-year totals distributed to new and repair and maintenance construction. The breakdown in 1926-1930 was made by applying the percentage distribution of new and repair construction for this period in P.I.C.F. Independent estimates of repair expenditure were developed in conjunction with direct estimates of major components of total construction for the period 1900-1930. These were inflated to full coverage on the basis of their relation to repair totals in the period 1926-1930. The relative coverage, base 1926-1930, was two-thirds for the period 19111930 and just over half for the decade 1901-1911 (see Table A-2). The quinquennial estimates of gross construction appear in Table 1 below.

In order to test the reliability of the method, 1941 was used as a bench-mark instead of 1921 . The resulting estimates were then compared with the estimates from the 1921 bench-mark in the five years of overlap from 1926 to 1930 . This approach also contributed to the reconciliation of the earlier series with the official estimates. ${ }^{12}$

Building and construction trade unions reported an average of 13.6 per cent unemployment from June 1, 1940 to May 31, 1941. ${ }^{13}$

${ }^{12} \mathrm{Cf}$. Table 4, below.

${ }^{13}$ Cf. Labour Gazette, Ottawa, Dept. of Labour, 1941. 
Average unemployment from all causes among all construction workers, census definition, during the same period was 29.42 per cent and slightly higher among unskilled workers. ${ }^{14}$ The total construction labor force in 1941 included 213,500 skilled construction workers, 14,000 other skilled, and 71,200 unskilled workers, a total of 299,000 workers. ${ }^{15}$ (The total of 50,000 unskilled workers reported for the construction industry proper was raised by 21,000 by applying the census skill ratio $(3: 1)$ to the skilled workers engaged in force account construction.) This total labor force, after adjusting for time lost, is the equivalent of 224,700 members working full time. The average full time working force reported in the Census of Construction in 1941 was 158,700. The total product was $\$ 639.8$ million. On this basis the product of the construction labor force would be $\$ 906$ million. Adding the P.I.C.F. estimate of construction by home-owners and the P.P.I. estimate of construction by farmers yielded an estimate of total construction for 1941 of $\$ 972$ million.

The material component was run back to 1926 with an index of the domestic disappearance of construction materials secured from the P.I.C.F. study. The ratios of materials used to total construction reported in the construction census from 1934 to 1941 were extrapolated to 1926 (following P.I.C.F., the 1937 ratio was assigned to 1929). The resulting estimates of total construction compare very closely with those derived from the 1921 bench-mark:

\begin{tabular}{crc}
1921 Bench-mark & & $\begin{array}{c}1941 \text { Bench-mark } \\
\text { Year }\end{array}$ \\
\hline 1926 & 703 & 715 \\
1927 & 783 & 789 \\
1928 & 940 & 919 \\
1929 & 1,046 & 1,002 \\
1930 & 928 & 939 \\
\hline
\end{tabular}

Machinery and Equipment. The supply method was used to estimate gross investment in machinery and equipment. The annual flow, at producers' prices, of the different types of machinery and equipment was secured from records of production, imports, exports, and re-exports (see Table A-3). These values were adjusted to cost to final users by adding amounts for trade margins,

${ }^{14}$ Decennial Census of Canada, 1941, Vol. 6, pp. 90 and 92.

1sIbid., Vol. 7, p. 670; and Census Bulletin, 1941, No. 0-6, pp. 10-11. 
freight charges, duties, and other taxes. The problem of setting up a classified list of machinery and equipment items was simplified by using the commodity list from P.I.C.F. as a starting point. Some minor items were dropped because they appeared to be intermediate goods or parts and some were added because of a difference in handling machinery and equipment installed by construction contractors. ${ }^{16}$ Quinquennial estimates of gross investment in machinery and equipment appear in Table A-4.

Inventories. The general approach to the problem of estimating investment in inventories was taken from P.l.C.F. The changes in each category of producers' inventories were estimated annually, when this was possible, otherwise quinquennially. Changes in physical quantities of each type of farm grain, farm livestock, and grain in commercial channels were expressed in current values by applying averages of the respective prices in each period. Changes in manufacturing, trade, and miscellane ous business inventories were estimated in constant dollars and converted to current dollars by applying indexes of average annual prices. ${ }^{27}$ The estimates of investment in inventories, by types, are shown in Table A-5.

Foreign lnvestment. Foreign investment or disinvestment was measured by the net balance of payments on all current international transactions. F. A. Knox applied the concepts and methods developed at DBS to extend the official estimates of Canada's balance of payments, which began with 1926, back to 1900.10 One revision was made in his estimates to eliminate a bias in the methods used to estimate credits on tourist transactions, ${ }^{10}$ the gold items were excluded, and the total Canadian production of

${ }^{16}$ Data on many of these installations were not available for early years. The major items are telephone and telegraph equipment, which were included as machinery and equipment.

${ }^{17}$ Appropriate price indexes were not available. The year-end index used was an average of DBS December and January indexes of wholesale prices. These indexes were also used to revalue inventories from cost to market price in years of rising prices. The index used to convert the values of the changes from constant to current dollars was the DBS annual index of wholesale prices.

${ }^{18} \mathrm{~F}$. A. Knox describes his estimates in Herbert Marshall et al., Canadian-American Industry, Toronto, Ryerson Press, 1936. His final estimates appear in his study, "Dominion Monetary Policy," mimeographed, Ottawa, King's Printer, 1939.

${ }^{19}$ The Canadian Balance of International Payments, 1926 to 1948, Ottawa, DBS, 1949, p. 125. 
gold entered as a credit item in their place. This adjustment eliminated the necessity of adding the net change in the monetary gold stock as a fifth component of gross investment. ${ }^{20}$

Summary: Gross Capital Formation, 1901-1930

The adequacy of the estimates of gross capital formation in Canada from 1901 to 1930 (Table 1) depends upon the nature of the service expected of them. The original purpose of the estimates was to establish the general trend and pattern of investment in the period of rapid development from 1900 to 1930.

\section{TABLE 1}

Quinquennial Estimates of Gross Capital Formation, Canada, 1901-1930

\begin{tabular}{lrrrrrrr}
\multicolumn{8}{c}{ (millions of dollars) } \\
\hline & $1901-$ & $1906-$ & $1911-$ & $1916-$ & $1921-$ & $1926-$ \\
& 1905 & 1910 & 1915 & 1920 & 1925 & 1930 \\
\hline 1. Construction & 681 & 1,439 & 2,007 & 2,122 & 2,271 & 3,109 \\
2. Machinery and equipment & 380 & 586 & 912 & 1,322 & 1,211 & 2,097 \\
3. Inventories & 222 & 262 & 360 & 589 & 159 & 625 \\
4. Gross domestic invest- & & & & & & \\
$\begin{array}{l}\text { ment (1) +(2) +(3) } \\
\text { 5. Foreign investment }\end{array}$ & 1,283 & 2,287 & 3,279 & 4,033 & 3,641 & 5,831 \\
6. Gross capital formation & -301 & -784 & $-1,515$ & -262 & 72 & -563 \\
$(4)+(5)$ & 982 & 1,503 & 1,764 & 3,771 & 3,713 & 5,268 \\
\hline
\end{tabular}

The two basic series, flows of construction materials (Table A-1) and machinery and equipment at producers' prices (Table A-3), may be firm enough to use on an annual basis. The records used in establishing these totals were reasonably good. However, the data available to support the procedures involved in passing from producers' prices to cost to final users were not good enough to make reliable annual estimates. This was particularly true of the construction series, which is shown annually in Table A-2 to indicate its relation to the material component. Another possible source of error in the construction estimates was the use of an independent repair series to determine the repair component. Finally there were not sufficient data to adjust the construction materials series for trade margins and inventory changes.

${ }^{20}$ If monetary gold movements are included in the current account as in the Knox series, their effect on total investment is merely offset by equal and opposite changes in gold stocks (P.I.C.F., p. 109). 


\section{CAPITAL FORMATION IN CANADA}

The machinery and equipment estimates are more reliable. The spread between producers' and final prices is, of course, smaller. The final estimates suffer from the arbitrary assumption of a flat trend in trade mark-ups and also from lack of adjustment for changes in inventories.

TABLE 2

Comparison of Direct with Global Estimates of Gross Construction, Canada, 1901-1930

\begin{tabular}{|c|c|c|c|c|c|}
\hline Period & $\begin{array}{c}\text { Steam } \\
\text { Rail- } \\
\text { ways. } \\
(1)\end{array}$ & $\begin{array}{c}\text { Federal } \\
\text { Provincial } \\
\text { and Municipal } \\
\text { Governments } \\
\text { (2) }\end{array}$ & $\begin{array}{c}\text { Housing } \\
\text { (3) }\end{array}$ & $\begin{array}{c}\text { Residual } \\
(5)-(1)-(2)-(3) \\
(4)\end{array}$ & $\begin{array}{c}\text { Gross } \\
\text { Construc- } \\
\text { tion } \\
\text { (5) }\end{array}$ \\
\hline \multicolumn{6}{|c|}{ (millions of dollars) } \\
\hline $\begin{array}{l}1901-1905 \\
1906-1910 \\
1911-1915 \\
1916-1920 \\
1921-1925 \\
1926-1930\end{array}$ & $\begin{array}{l}124 \\
381 \\
537 \\
253 \\
253 \\
389\end{array}$ & $\begin{array}{r}79 \\
149 \\
342 \\
256 \\
436 \\
578\end{array}$ & $\begin{array}{r}222 \\
46 \dot{8} \\
568 \\
641 \\
742 \\
1,060\end{array}$ & $\begin{array}{r}256 \\
441 \\
560 \\
972 \\
840 \\
1,082\end{array}$ & $\begin{array}{r}681 \\
1,439 \\
2,007 \\
2,122 \\
2,271 \\
3,109\end{array}$ \\
\hline \multicolumn{6}{|c|}{ (percentage distribution) } \\
\hline $\begin{array}{l}1901-1905 \\
1906-1910 \\
1911-1915 \\
1916-1920 \\
1921-1925 \\
1926-1930\end{array}$ & $\begin{array}{l}18.2 \\
26.5 \\
26.8 \\
11.9 \\
11.1 \\
12.5\end{array}$ & $\begin{array}{l}11.6 \\
10.4 \\
17.0 \\
12.1 \\
19.2 \\
18.6\end{array}$ & $\begin{array}{l}32.6 \\
32.5 \\
28.3 \\
30.2 \\
32.7 \\
34.1\end{array}$ & $\begin{array}{l}37.6 \\
30.6 \\
27.9 \\
45.8 \\
37.0 \\
34.8\end{array}$ & $\begin{array}{l}100.0 \\
100.0 \\
100.0 \\
100.0 \\
100.0 \\
100.0\end{array}$ \\
\hline
\end{tabular}

a Direct investment in steam railways by the federal government is included in column 1. For the amounts involved, see Table A-6.

The inventory estimates are the least reliable of the major components. Some records of farm inventories were available before 1915. The manufacturing inventories from 1900 to 1910 were obtained by applying the 1915 ratio to the earlier statistics of total working capital. The trade inventories were assumed to bear a constant relation (over a period of twenty-five years) to total export and import commodity trade. Before 1915 when the data upon which the inventory estimates are based are least satisfactory, inventories account for 20 to 22 per cent of gross capital formation. They are relatively less important after 1915 .

Table 2 provides a comparison between direct estimates of three major components of new construction, steam railways, gov- 
ernment, and housing construction, ${ }^{21}$ and the construction estimates appearing in Table 1 . It is remarkable that these three components of gross construction should account for so much of the total. The railway and government components are firm estimates, but even allowing for some inflation in the housing estimate, the level of the estimates of gross construction may be too low.

The movement of the residual does not appear unreasonable. The relative decline from 37.6 per cent in 1901-1905 to 30.6 per cent in 1906-1910 is expected in view of the great increase in railway construction. (Two transcontinental railways were under construction in this period.) Part of the decline may be the product of error in the housing series. The further decline in the relative importance of the residual category to 27.9 per cent in 19111915 can be attributed to a sensitive response of commerce and industry to the recession and depression from mid-1913 to 1915, while railway and government investment were maintained at high levels. In the following five years, commerce and industry were stimulated by the war. Hydro installation and power and light became important factors after 1915. At the same time housing construction was depressed and government and railway construction were restrained.

A general check on the estimates, although far from conclusive, may be made by comparing the estimates with GNP. ${ }^{22}$ To facilitate this comparison, gross capital formation was adjusted by deducting direct government investment and adding back the deficits of governments. The measure of gross domestic savings obtained in this way was expressed as a percentage of GNP in each quinquennium from 1901 to 1930 (Table 3).

Ignoring the inflated years 1916-1920, Table 3 shows a remarkably stable relationship between gross savings and GNP. If one assumed no change in the disposition to save over the period, the estimates would appear to be mutually corroborative since on that assumption the minor changes in the proportion of GNP saved may be plausibly explained in terms of known variations in the level of domestic income. In the quinquennium 1926-1930 an average of 17.6 per cent of GNP was saved. Since the GNP for these years is the official estimate, this average provides a reliable

${ }^{21}$ For annual series of investments of federal and provincial governments and steam railways see Tables A-6 and A-7.

${ }^{22}$ The estimates of GNP are very rough. For a description of their derivation see note to Table A-8. 
TABLE 3

Gross Savings Offsets, Canada, 1901-1930

(dollars in millions)

\begin{tabular}{|c|c|c|c|c|c|}
\hline Period & $\begin{array}{c}\text { Private Gross } \\
\text { Domestic } \\
\text { Investment } \\
\text { (1) }\end{array}$ & $\begin{array}{c}\text { Government } \\
\text { Deficits } \\
\text { (2) }\end{array}$ & $\begin{array}{l}\text { Capital } \\
\text { Inflows } \\
\text { (3) }\end{array}$ & $\begin{array}{l}\text { Private Gross } \\
\text { Domestic } \\
\text { Savings } \\
(1)+(2)-(3) \\
\text { (4) }\end{array}$ & $\begin{array}{c}\text { Gross } \\
\text { Savings } \\
\text { as Per Cent } \\
\text { of GNP } \\
\text { (5) }\end{array}$ \\
\hline $\begin{array}{l}1901-1905 \\
1906-1910 \\
1911-1915 \\
1916-1920 \\
1921-1925 \\
1926-1930\end{array}$ & $\begin{array}{r}\$ 1,189 \\
2,039 \\
2,839 \\
3,741 \\
3,202 \\
5,229\end{array}$ & $\begin{array}{r}40 \\
255 \\
770 \\
2,195 \\
525 \\
400\end{array}$ & $\begin{array}{r}301 \\
784 \\
1,515 \\
262 \\
-72 \\
563\end{array}$ & $\begin{array}{r}928 \\
1,510 \\
2,094 \\
5,674 \\
3,799 \\
5,066\end{array}$ & $\begin{array}{l}16.5 \\
16.9 \\
15.8 \\
25.2 \\
16.8 \\
17.6\end{array}$ \\
\hline
\end{tabular}

base for comparison. With the exception of 1930, a depression year, these were prosperous years. Assuming no change in the disposition to save, one would expect to find the average running at about the same level from 1901 to 1910 , as it appears to have done. There were minor recessions in 1901 and 1904 and a more severe recession in 1907-1908. The first major break in the prewar expansion came after the peak of 1912-1913. The recessive tendency continued into 1915. This depression would account for the lower relative gross savings in 1911-1915. Although the period of severe unemployment during 1921-1922 was brief, it is surprising to find the rate of gross savings so high from 1921 to 1925. However, the worst of the depressions from 1900 to 1930 was mild compared with that experienced after 1930; the whole period 19001930 was characterized by a general prosperity and expansion without parallel in the country's development.

If an approximate allowance is made for replacements, the net addition to durable physical assets during 1916-1920 is lower than during 1911-1915 even when the values are expressed in current dollars. In view of the inflation accompanying the war the drop in volume must have been considerable (average construction costs were over 50 per cent greater from 1916 to 1920 than from 1911 to 1915). Additions to farm and business inventories at 2.8 per cent of GNP are not unreasonable considering the great expansion of manufacturing and agricultural output during this period. Thus the proportion of GNP saved and channeled into private capital formation was only slightly lower than in other prosperous periods. Superimposed on this level of savings was an additional 10 per cent induced by deficit spending and absorbed by the federal 
government to finance the deficits. The federal government, without access to foreign capital markets and unwilling to alter radically the prevailing system of taxation, relied upon domestic bond sales to war-enriched corporations and individuals. This primitive method of financing the war greatly distorted the distribution of money income. Deutsch has estimated that 75 per cent of all war bond subscriptions were from large corporations and wealthy people who reaped the profits of inflation. ${ }^{23}$ In view of the method of financing the war, the high rate of gross savings indicated in Table 3 is not surprising.

\section{Reconciliation}

This section deals with the levels and trends in the estimates of capital formation from 1926 to 1941 . The possibility of linking the 1901-1930 series with the official estimates from 1926 to 1941 is examined to establish a series from 1901 to 1941 that is consistent with the current official estimates from 1941 to the present.

\section{Relation of 1901-1930 Series to the P.I.C.F. Series}

Construction. In P.l.C.F., engineering construction was estimated directly for the period 1926-1941 and total building construction was estimated by applying the annual flow of building materials to a 1941 bench-mark and raising the result. In the 19011930 estimates, total construction was estimated by this indirect method. The bench-mark estimates in both series were made by inflating a construction census total, but in different ways. The results obtained for the overlapping years in the two series were very close. The totals for the five years 1926-1930 differ by less than 1 per cent. Annual differences did, not exceed 4 per cent and might be attributed to the lack of inventory adjustments in the commodity flow used in the 1901-1930 estimates.

The P.l.C.F. totals also checked very closely for the period 1926-1941 with the "1941 test series," which was derived by the same method as the 1901-1930 series (Table 4).

In view of the close agreement between the 1901-1930 estimates and P.I.C.F. in the period 1926-1930 and between the quinquennial totals in P.I.C.F. and the 1941 test series, the quinquennial totals from 1901 to 1925 may be taken as they stand along with totals from P.I.C.F. to form a series from 1901 to 1941.

23. J. Deutsch, "War Finance and the Canadian Economy," Canadian Journal of Economic and Political Science, Vol. 6, 1940, pp. 538-539. 
TABLE 4

Comparison of Estimates of Total Construction, Canada, 1926-1941

(dollars in millions)

\begin{tabular}{rccccc}
\hline Period & $\begin{array}{c}1901-1930 \\
\text { Series } \\
(1)\end{array}$ & $\begin{array}{c}\text { P.I.C.F. } \\
\text { Series } \\
(2)\end{array}$ & $\begin{array}{c}1941 \text { Test } \\
\text { Series } \\
(3)\end{array}$ & $\begin{array}{c}\text { Ratio of } \\
\text { (1) to (2) } \\
(4)\end{array}$ & $\begin{array}{c}\text { Ratio of } \\
(3) \text { to (2) } \\
\text { (5) }\end{array}$ \\
\hline $1926-1930$ & $\$ 4,400$ & $\$ 4,375$ & $\$ 4,363$ & 1.006 & 0.997 \\
$1931-1935$ & & 2,561 & 2,595 & & 1.013 \\
$1935-1940$ & & 3,253 & 3,230 & & 0.993 \\
1941 & & 951 & 972 & & 1.022 \\
\hline
\end{tabular}

Machinery and Equipment. In addition to the difference in the methods of segregating machinery parts in the production totals of the 1901-1930 estimates and P.I.C.F. ${ }^{24}$ there were some differences in scope. The 1901-1930 series included an allowance for business use of passenger cars and P.I.C.F. did not. This adjustment would raise the P.I.C.F. total for the quinquennium 1926-1930 from $\$ 1,980$ million to $\$ 2,170$ million. The total for the same years in the 1901-1930 series is $\$ 2,097$ million. The difference of 3.5 per cent is the result of the changes in the commodity classifications cited above (page 99). Accordingly the two series may be linked by raising the estimates of machinery and equipment from 1901 to 1925 by this amount and adding an allowance for the business use of passenger cars to the P.I.C.F. estimates. $^{23}$

Inventories. The inventory estimates in the 1901-1930 series are consistent with P.I.C.F., but the actual estimates of P.I.C.F. are no longer the best available for the period after 1926. P.I.C.F. is the only published source for investment in inventories held directly by governments. The best available estimates for other inventories from 1926 to the present may be secured from recent issues of the DBS publication, National Accounts, Income and Expenditure, by deducting the item "inventory valuation adjustment" from the inventory investment shown in the accounts. Combining these with the inventory component from Table 1 above

${ }^{24}$ See p. 93 above. Parts were segregated in the initial tabulations of production totals in the 1901-1930 series.

${ }^{2}$ Annual estimates of the size of this allowance have been made by the Canadian Dept. of Trade and Commerce. They are included in the machinery and equipment series in the national accounts published in 1950. (Before revision by P.P.I., the P.I.C.F. estimates were used in the national accounts.) 
provides a series that is consistent conceptually from 1901 to the present. ${ }^{26}$

Foreign lnvestment. The foreign investment component shown in Table 1 is consistent with P.I.C.F. Only minor revisions have been made since P.I.C.F. was published, and these may be obtained in current issues of National Accounts, Income and Expenditure.

Inventories and foreign investment were not covered in P.P.I. The remaining task of reconciling estimates of construction and investment in machinery and equipment from 1926 to 1941 turned upon the relation between the P.I.C.F. estimates and the revisions in P.P.I.

Relation of the Estimates in P.P.I. and P.I.C.F.

The levels of the estimates of total construction and gross investment in machinery and equipment in P.P.I. do not compare very closely with those of P.I.C.F. and the trend in the machinery and equipment series differs quite radically from the earlier series.

Construction. The major change in method in P.P.I. was to obtain total building construction as the sum of direct estimates for each user category. The earlier housing estimates were completely revised and the bulk of the expenditures on building construction for the categories treated as a residual in P.I.C.F. (industrial, commercial, institutional, and other building) was now derived from the National Revenue sample of corporations mentioned above. The revised series of new and repair construction fluctuated somewhat more than the P.I.C.F. series but the most striking difference was the higher level of the P.P.I. estimates (Table 5).

The P.P.I. estimates are 16.5 per cent higher from 1926 to 1930 , 13.6 per cent from 1931 to 1935 , and 16.1 per cent from 1936 to 1940. Since the differences in year-to-year movements in the two series largely cancel out, the movements on a quinquennial basis are fairly uniform. When the 1941 estimate of P.P.I. was projected to 1926 on an index of the 1941 test series described above, the series obtained did not differ in quinquennial totals from the P.P.I. series by more than 2.25 per cent. This uniformity would support the projection of the P.P.I. estimates to 1901 with a quinquennial index of the 1901-1930 series.

${ }^{26}$ The poor quality of the estimates of inventory investment before 1925 has been emphasized in section 2, above. 
TABLE 5

Comparison of New and Repair Construction Estimates, Canada, 1926-1941

\begin{tabular}{|c|c|c|c|}
\hline Year & $\underset{\text { (1) }}{P . I . C . F .}$ & $\begin{array}{c}P . P .1 .{ }^{\mathrm{a}} \\
(2)\end{array}$ & $\begin{array}{l}\text { Ratios of } \\
\text { (2) to (1) } \\
\text { (3) }\end{array}$ \\
\hline $\begin{array}{l}1926 \\
1927 \\
1928 \\
1929 \\
1930\end{array}$ & $\begin{array}{r}701 \\
764 \\
914 \\
1,036 \\
960\end{array}$ & $\begin{array}{r}899 \\
915 \\
1,091 \\
1,210 \\
1,081\end{array}$ & $\begin{array}{l}1.140 \\
1.198 \\
1.194 \\
1.168 \\
1.128\end{array}$ \\
\hline Total 1926-1930 & $\overline{\$ 4,375}$ & $\$ 5,096$ & $\overline{1.165}$ \\
\hline $\begin{array}{l}1931 \\
1932 \\
1933 \\
1934 \\
1935\end{array}$ & $\begin{array}{r}\$ 84 \\
485 \\
364 \\
434 \\
494 \\
\end{array}$ & $\begin{array}{r}866 \\
550 \\
427 \\
502 \\
564 \\
\end{array}$ & $\begin{array}{l}1.105 \\
1.134 \\
1.173 \\
1.157 \\
1.142 \\
\end{array}$ \\
\hline Total 1931-1935 & $\overline{\$ 2,561}$ & $\$ 82,909$ & $\overline{1.136}$ \\
\hline $\begin{array}{l}1936 \\
1937 \\
1938 \\
1939 \\
1940\end{array}$ & $\begin{array}{r}540 \\
684 \\
633 \\
640 \\
756\end{array}$ & $\begin{array}{r}631 \\
781 \\
737 \\
759 \\
869\end{array}$ & $\begin{array}{l}1.169 \\
1.142 \\
1.164 \\
1.186 \\
1.149\end{array}$ \\
\hline Total 1936-1940 & $\overline{\$ 3,253}$ & $\overline{\$ 3,777}$ & $\overline{1.161}$ \\
\hline 1941 & $\$ 951$ & $\$ 1,137$ & 1.196 \\
\hline
\end{tabular}

ancludes nonconstruction expenditures by governments on resource development.

Part of the increase in fluctuation may be the result of the full adjustment for inventory changes implicit in the method of P.P.I. as opposed to the partial adjustment achieved in P.I.C.F., but since the range in fluctuation over the whole series was increased by about 9 per cent and some of the annual changes by almost 5 per cent, e.g. 1926-1927 and 1940-1941, other factors must be involved. If the revised series were accurate, the other factors operating in the P.l.C.F. estimates could be variations in trade margins and freight charges on building materials, changes in the ratio of intermediate to finished goods included in the building material series, errors in the extrapolation from 1934 to 1926 of ratios of materials used to total building construction, and inadequate measurement of the flow of building materials to nonconstruction uses. In view of this array of possibilities, it is surprising that the difference in the relative fluctuations in the two series is not greater. 
The difference in the level of the two series is easier to explain. If the P.P.I. estimate for 1941 is reliable, the bench-mark estimate of P.I.C.F. is too low. Excluding from the P.P.I. figure the nonconstruction outlay on resource development by governments, the difference in 1941 is $\$ 186$ million. Most of this difference arose from the higher provision for housing construction in P.P.I., ${ }^{27}$ and since the figure for urban housing was about the same in both studies, the difference was attributable largely to housing repair, new rural nonfarm housing, major alterations, and a small addition in P.P.I. for labor in farm construction.

In the earlier years the relative difference in the two series was roughly the same, but its pattern changed because of an upward bias in the P.I.C.F. estimates for urban housing. For 1941 the P.I.C.F. estimate for the residual group was somewhat higher than the sum of the P.P.I. estimates for manufacturing, construction, trade, finance, commercial services, minor utilities, and private institutions. In the estimates for the earlier years this relationship is reversed because of the greater weight given to urban housing in P.I.C.F.

Gross Investment in Machinery and Equipment. A comparison of the estimates of investment in machinery and equipment appearing in P.I.C.F. and P.P.I. indicates that if either is reliable, the other is markedly biased (Table 6).

There are several reasons to expect a difference in the levels of the two series; but none of these explains the great difference in trend. ${ }^{28}$ For example data for full adjustment for inventory changes were not available to the authors of P.I.C.F. Furthermore the method of segregating parts from combined totals of finished goods and parts in the trade reports was to apply a flat percentage, but the frequency of this procedure was too low to introduce more than a slight narrowing of the range of fluctuation between prosperous and depressed years. Finally P.l.C.F. should be lower in all years for two reasons: No additions were made for installation costs or for the business use of passenger cars.

It is difficult to find anything in the sources and procedures of P.I.C.F. that would introduce errors of the size implied in

${ }^{27}$ The new housing estimates are from O. J. Firestone, Residential Real Estate in Canada, University of Toronto Press, 1951.

${ }^{28}$ The comparison is limited to new investment. The partial repair series in P.I.C.F. runs, with fair uniformity, at about 20 per cent of the level of the full repair series in P.P.I. Cf. P.I.C.F., pp. 40-41, and P.P.I., p. 152. 
CAPITAL FORMATION IN CANADA

TABLE 6

Comparison of Estimates of Gross Investment in New Machinery and Equipment, Canada, 1926-1941

(dollars in millions)

\begin{tabular}{cccc} 
Year & $\begin{array}{c}\text { P.I.C.F. } \\
(1)\end{array}$ & $\begin{array}{c}P . P . I . \\
(2)\end{array}$ & $\begin{array}{c}\text { Ratio of } \\
(2) \\
\text { to }(1)\end{array}$ \\
\hline 1926 & $\$ 293$ & $\$ 371$ & 1.266 \\
1927 & 360 & 451 & 1.253 \\
1928 & 423 & 509 & 1.203 \\
1929 & 503 & 620 & 1.233 \\
1930 & 401 & 497 & 1.239 \\
1931 & 220 & 283 & 1.286 \\
1932 & 131 & 161 & 1.229 \\
1933 & 100 & 95 & 0.950 \\
1934 & 149 & 130 & 0.873 \\
1935 & 177 & 163 & 0.921 \\
1936 & 236 & 198 & 0.839 \\
1937 & 366 & 304 & 0.831 \\
1938 & 327 & 300 & 0.917 \\
1939 & 305 & 279 & 0.915 \\
1940 & 495 & 464 & 0.938 \\
1941 & 696 & 655 & 0.941 \\
\hline
\end{tabular}

Table 6. The annual production and trade records are good. The domestic industries producing machinery and equipment are highly concentrated and for that reason relatively easy to cover. It is therefore unlikely that there is a rising trend in the coverage of the Census of Industry. There is no evidence of discrepancies between the direct estimates available to P.I.C.F. and the estimates based on commodity flows. Checks were made for industrial machinery and equipment in 1941 and for railway equipment in all years. ${ }^{20}$ The estimates for automobiles and farm machinery and equipment were close enough to sales in the overlapping years to use the differences to extrapolate margins to earlier years. ${ }^{30}$ There were some arbitrary adjustments from producers' to final prices in the P.I.C.F. series, but the largest items, the trade margins, were supported by two decennial censuses as well as intercensal surveys of the trade channels involved. Furthermore the average spread between producers' and final prices was not large relative to final totals. Gross errors in the adjustments would not account for the differences evident in Table 6.

${ }^{20}$ P.I.C.F., p. 121.

solbid., p. 107. 
The bulk of the new direct estimates of expenditures on machinery and equipment in P.P.I. was based on a sample of corporations reporting to the Department of National Revenue. Manufacturing, construction, trade, finance, and commercial services were the categories covered in the sample. The following procedure for manufacturing illustrates the method used. The "estimates are based on the tax records of 358 companies engaged in manufacturing in 1946 and active during the preceding 20-year period. To ensure comparability throughout the period the records of the same companies have been used irrespective of change in legal status. For example, if one company which had been formed as the result of a merger in 1938 was operating in 1946, the records of this company formed the basis for the years 1939 to 1946 and the records of the predecessor companies would be used for the period 1926 to $1938 .{ }^{31}$... The 358 companies reported gross sales of $\$ 3,016$ million in $1946 \ldots 38$ per cent of the gross value of production by manufacturing industry amounting to $\$ 8,036$ million.

"The 358 firms, selected on the basis of the industrial classification... were arranged in size groups, usually three or four within each industrial group, according to the size of the gross sales of the companies in 1945 or 1946 . The corporate universe from which the sample was drawn was similarly grouped, and the ratio of universe sales calculated separately for each size group in each of the industrial classifications involved. These ratios were applied as blow-up factors to the sample data on capital and repair and maintenance expenditures for the years 1926 to 1946 inclusive. The resulting absolutes for each industrial group were then converted into a series of index numbers with 1946 as the base year. This index was applied to capital and repair and maintenance expenditure estimated for $1946 \ldots{ }^{32}$ by the survey method described in section 1 of this paper.

Several observations are relevant:

1. The blow-up factor applied over the twenty-year period was a constant sales ratio based on 1945 or 1946 . Sales ratios may be a fairly reliable blow-up factor for the base year, but a considerable variation could occur in the relative importance of each sample segment in its group over a twenty-year period.

\footnotetext{
31 Data for previously existing companies could only be used, however, if they were incorporated. Data were not available for unincorporated companies.

32P.P.I., p. 223.
} 
2. The sample was a corporate one. The ratio of sales of incorporated to unincorporated companies was high in manufacturing and finance and its variation probably slight. The same was not true for construction, trade, or commercial services.

3. It would be difficult to track down all the concerns absorbed by members of the samples and these could only be added to the sample if they were incorporated companies. All the errors in this procedure would work in the same direction.

4. Another difficulty, and probably the most important, was the problem of eliminating all purchases of existing assets. This would be particularly acute for the period before 1929, the most distant in time, and also the period when the number of consolidations was highest.

According to the Report of the Royal Commission on Price Spreads, of 721 corporations absorbed in consolidations from 1921 to 1930,574 were absorbed from 1926 to 1930 , and 344 of these were absorbed in the two years 1928 and 1929.3s Most of these were manufacturing firms; 162 commercial corporations were included in the total. ${ }^{34}$ Absorptions were particularly high in the food and beverage group..$^{35}$

The method of sampling would tend to select companies that were active in the acquisition of existing assets and one might reasonably doubt that a complete record of these acquisitions could be assembled. One would expect an upward bias in the extrapolations for the period of the late 1920's. Since the consolidations varied cyclically, one would also expect the bias to he least marked in the trough of the depression. The validity of this explanation of the difference in trend in the P.I.C.F. and P.P.I. estimates of new investment in machinery and equipment cannot be tested in this paper, but sufficient data can be adduced to indicate that some further research on the subject is warranted.

It is difficult to conceive of a better check on the sample estimates than the flow series in P.I.C.F. Among the rough comparisons that might be made is the proportion of industrial machinery and equipment in the total flow of P.I.C.F. compared with the proportion of expenditure by the manufacturing industry in the

\footnotetext{
${ }^{33}$ Report of the Royal Commission on Price Spreads, Ottawa, King's Printer, 1935, p. 28.

s4lbid., p. 332.

35 In the food and beverage group: 3 fruit and vegetable firms absorbed 52 concerns; 4 milling companies absorbed $47 ; 13$ liquor companies absorbed 61; 9 dairies absorbed 57 (ibid., pp. 332-340).
} 
total expenditure on new machinery and equipment reported in P.P.I. In P.I.C.F. industrial machinery and equipment accounted for very close to 30 per cent of all machinery and equipment in every year from 1926 to 1939 . In 1940 and 1941 the percentage rose. In P.P.I. the manufacturing component of total expenditure on new machinery and equipment accounted for about 41 per cent of the total from 1926 to 1932 and about 28 per cent from 1933 to 1941 .

The highest number of absorptions in manufacturing in the 1920's occurred in the food and beverage industry. This group, in the industrial classification currently in use, corresponds closely with the animal and vegetable product groups in the older industrial classification. According to the P.P.I. estimates, the food and beverage group accounted for over one-third ( $\$ 546$ million of $\$ 1,480$ million) of all new investment in durable physical assets in manufacturing from 1926 to 1930 , and for about 50 per cent of the investment in new machinery and equipment in the same period. These percentages were fairly well maintained through 1931 and 1932. From 1933 to 1941 both dropped to under 20 per cent. ${ }^{26}$ If one could rely on production or sales ratios, 20 per cent is about what one would expect in the period before 1933. On the basis of the definitions employed in the Census of Industry in 1941, the animal and vegetable product groups accounted for 19.4 per cent of the net production of manufacturing in 1941 and 18.5 per cent in 1929. On the basis of the definitions in use in 1929, the percentage was 23.4 per cent in that year and slightly higher, 24.5 per cent, in 1926. The number of employees in the animal and vegetable product industries was $24.2,23.8$, and 20.4 per cent of all manufacturing employees in 1926, 1929, and 1941, respectively. Again, following the definition of capital employed in the Census of Industry in 1941, i.e. valued at replacement cost, the animal and vegetable product groups held 21.3, 20.9, and 19.1 per cent of total capital employed in manufacturing in 1926, 1929, and 1941, respectively. Finally following the census definition of durable capital in the Census of Industry before 1930, i.e. valued at original cost, the value of land, structures, and machinery and equip-

00 P.P.I., pp. 156 and 158 . Even the postwar peak of $\$ 56.5$ million of new investment in machinery and equipment fell far short of the 1928 level, when it was $\$ 130.9$ million. These values are in current dollars; the difference in volume would be greater. This is hard to believe in the face of the higher level of income and population in the later period, especially when these follow a long period of relatively depressed investment in the industry. 
ment in all manufacturing industries increased by $\$ 853$ million in the four years of expansion from 1926 to 1929; the share in this total increment of the animal and vegetable product groups was only $\$ 71$ million. These data appear to refute the P.P.I. estimates for the food and beverage industry. If there was a bias in this series, a similar bias might also exist, in smaller degree, in other components derived by the same method. In any event the suggestion is raised here as a possible explanation of the difference in the estimates shown in Table 6.

\section{Conclusions}

This paper has presented new estimates of gross capital formation in Canada from 1901 to 1930. In addition procedures for linking three of the four major components of the 1901-1930 series with the official estimates from 1926 to the present have been described. Gross investment in machinery and equipment in the 1901-1930 series was found to be inconsistent with the estimates of P.P.I. An internally consistent series could be established by linking the 1901-1930 machinery and equipment series with the revised P.I.C.F. estimates used in the national accounts until 1950.37 The revised P.I.C.F. series was linked in this source with the current estimates based on the capital survey. A distinct disadvantage of this expedient is that the machinery and equipment series obtained would not agree with the present version of the official estimates from 1926 to 1940 or-if it seems preferable to the user to advance the base of projection-to 1945. Furthermore the suggestion of bias in the P.P.I. estimates, apparently confirmed above for one component of the estimates, may be refuted when a full account of the processing of the national revenue sample is made available to users outside the government. In this event a projection of P.I.C.F. to 1901 would be invalid.

Some direct estimates of gross investment by major categories bave also been presented for the period beginning with 1901 . The estimates for housing, 1901-1921, for municipal investment, ${ }^{38}$ and GNP; 1901-1925, are crude. At best they may be fair approximations. The other direct estimates are more reliable. With the exception of housing, these direct estimates conform with official

JIf this expedient is followed, direct government investment in new machinery and equipment from P.P.I. should be added to the national accounts series, which excluded it.

30Municipal investment is included in the quinquennial totals of govemment investment in section 2 . Federal and provincial investment on an annual basis are shown in Table A-6. 
estimates for the same categories in P.I.C.F. and.P.P.I. The housing estimates are based on the methods of P.P.l. and the estimates for investment in nonfarm housing, 1921-1930, are from that study. ${ }^{39}$ Prairie farm-housing investment from 1921 to 1931 was estimated on the basis of the quinquennial censuses of the prairie provinces. In P.P.I., estimates for this sector are based on the decennial censuses of 1921 and 1931 .

Since the direct estimates, 1901-1930, conform with those in P.P.I., the estimates of construction in these categories are also consistent with a projection of the P.P.I. level of all construction to 1901. They are not consistent with the level of construction in the 1901-1930 series itself. The method of determining the level of construction in the 1901-1930 series-an inflation of the Census of Construction on a labor input ratio-apparently underestimated the level of construction in both 1921 and 1941. A similar result can be demonstrated for 1940 . The construction labor force in 1940 was enumerated in the national registration of that year. Raising the Census of Construction total for that year by the present method yielded an estimate of total construction of $\$ 750$ million, which is 14 per cent below the P.P.I. estimate for 1940. An application of a similar method to the 1940 data, over a decade ago, yielded an estimate of $\$ 869$ million for 1940 , which agrees precisely with the P.P.I. estimate for the same year. ${ }^{40}$ In this estimate, which was made before the results of the 1941 census were available, it was assumed that unemployment would be relatively lower among construction workers outside the unions than among union members. ${ }^{41}$ Subsequently the decennial census showed this to be in error. Correcting the adjustment for unemployment in the estimating procedure on the basis of the decennial census record would reduce the estimate from $\$ 869$ million to $\$ 687$ million. ${ }^{42}$

${ }^{30}$ The estimates of investment in housing cover expenditures on new units only. The P.P.I. estimates include expenditures on major alterations as well.

${ }^{40} \mathrm{O}$. J. Firestone, "Estimate of the Gross Value of Construction in Canada, 1940," Canadian Journal of Economics and Political Science, May 1943, pp. 219-234.

41 lbid., p. 231.

42Average unemployment among construction trade-union members in 1940 was 20.1 per cent. This was reduced to 17.0 per cent. The decennial census reports an average of 29.42 per cent unemployment among male construction workers and slightly more among unskilled laborers and females in construction jobs during the year June 1, 1940 to May 31, 1941 (Decennial Census of Canada, 1941, Vol. 6, pp. 90 and 92). The trade-union average for this period is 13.6 per cent. The implied ad- 


\section{CAPITAL FORMATION IN CANADA}

The level of the construction estimates of P.P.I. was not questioned in this paper. The possibility of bias was raised in the comments on the national revenue sample, but none was indicated in the comparison with the series based on the flow of construction materials. Apart from housing, the other major components of the construction estimates of P.P.I. were based on consistent records. Housing estimates for recent years were also confirmed in most respects by apparently firm data. ${ }^{43}$ The gross increases in dwelling units by decades were derived largely from the decennial census. The distribution of decade totals to an annual basis was achieved with indexes of the annual domestic disappearance of construction materials used predominantly in housing. In the writer's opinion, the values applied, particularly in the prewar years, are the element in the estimates most subject to error. Units were valued in a single year by average prices for each of the main types (nonfarm single, multiple, farm etc.) derived from samples. The quality of the units within each type varied widely. The average prices applied were apparently but not demonstrably representative owing to the lack of anything like a complete record for any one year. These average prices were then projected to other years on an index that combined, with constant weights, the wage-rate and material-price indexes. Allowance for variations in the productivity of labor were introduced in some recent years when variations were evident, but there were no data to allow for variations that might have occurred in most of the years to which the average prices were projected. As experience in estimating the current level of investment in housing accumulates, more light is thrown upon the estimates for earlier years. At the present juncture the level and pattern of these estimates have not been seriously questioned. It is this evidence that supports the conclusion that the P.I.C.F. bench-mark estimate was too low.

The underestimate of the level of construction derived by inflating the Census of Construction with a labor-input ratio may be considered in the light of the following possibilities:

justment would reduce the estimate of skilled construction workers not covered by the Census of Construction from 68,100 to $21,000-$ complementary workers would be reduced in the same proportion - and the addition to total construction on their account reduced from $\$ 380$ million to $\$ 118$ million. In the original estimate the $\$ 380$ million was reduced by $\$ 80$ million to allow for error. Without this allowance the estimate for 1940 would be $\$ 687$ million, i.e. $869-300+118$.

45 For a detailed account of sources and procedures see Firestone, Residential Real Estate in Canada. 
1. The level depends upon the ratios of materials, labor, overhead, and profit to total construction in the Census of Construction. These may be wrong. In particular it always seemed to the writer that the share of overhead and profit in the total was too low. There may be a downward bias originating in a reluctance to report full profits and, in view of the nature of many firms in the industry, an inability to recognize, let alone report, all overhead costs. Also the share of general overhead imputable to force account work may not be reported.

2. Even if average earnings in the full construction labor force and the portion of it covered by the construction census were the same, the product of the latter may not be representative of the former. The method assumed that materials used, equipment overhead, etc. were relatively the same in each group.

3 . The method also assumed that the ratio of skilled construction workers to complementary workers, chiefly unskilled, was the same for force account work as in the construction industry proper. On this assumption complementary workers outside the construction industry might be underestimated.

4. Finally the estimate of the product of persons outside the construction labor force might be low.

Among the tasks remaining are the development of more adequate deflators and the estimation of capital consumption. Estimates of gross investment should also be extended back to 1867, the date of the establishment of the Dominion. The extension of the estimates to earlier years will be hampered by the greater deficiency of production records since the quinquennial Census of Manufacturing began in 1906, and prior to that date only the decennial census was taken. However, annual trade records are available over the early period, and since import taxes were levied, the quality of these records is fairly good. A major difficulty in the extension of the estimates of the flow of construction materials is the inconsistency in the procedures of obtaining totals of woodproduct production and in the descriptions of these procedures in the decennial census. On the other hand the problem of establishing estimates of capital formation before 1900 is eased by the predominance of agriculture in the economy and the availability of various relevant provincial records. ${ }^{44}$ In addition government records are good, and since government intervention has been an important factor in Canadian development, these are useful sources.

${ }^{4}$ No allowance is made in Canadian estimates of capital formation for expenditures by farmers on land preparation. Such a series is being prepared for prairie agriculture. 


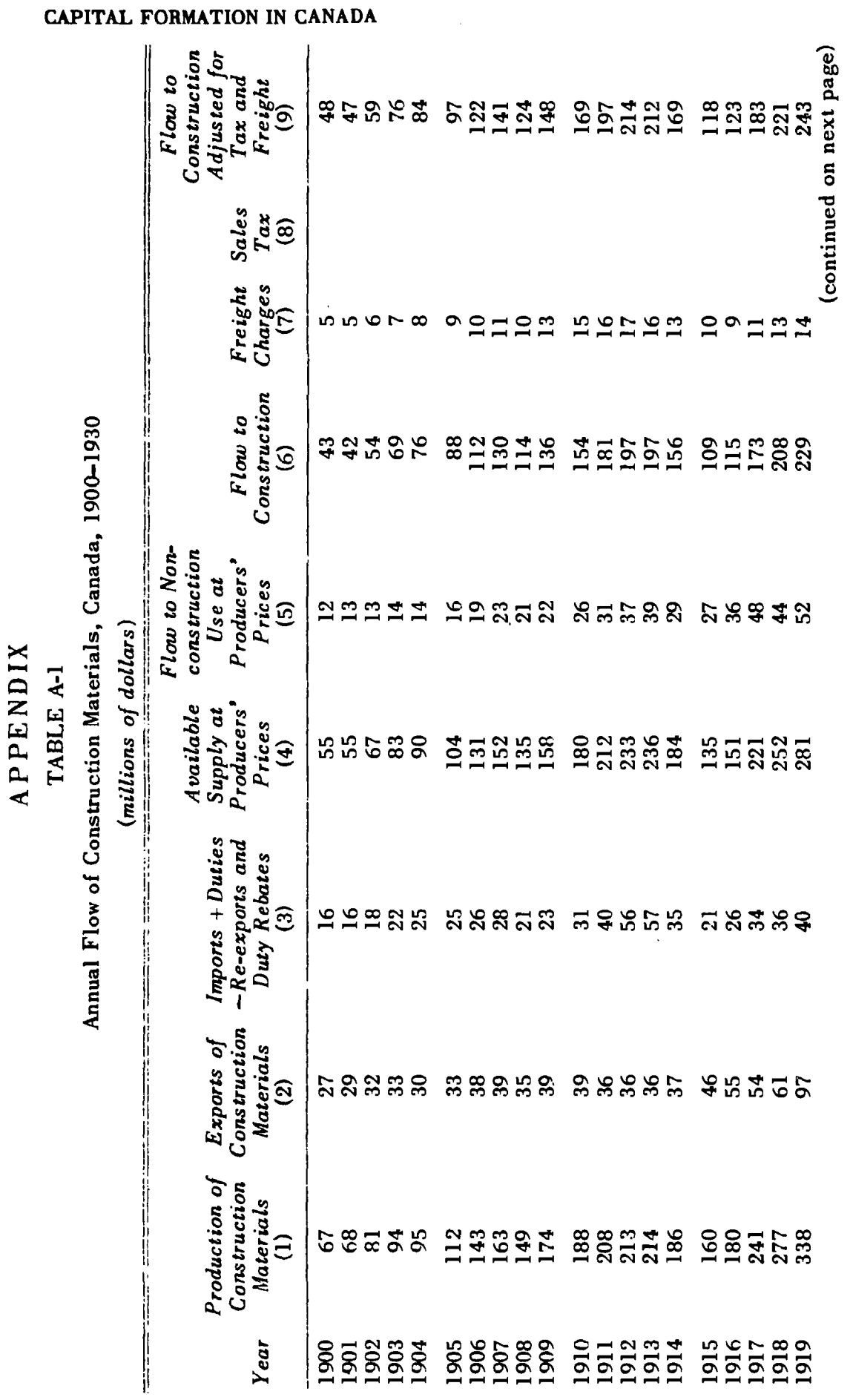


CAPITAL FORMATION IN CANADA

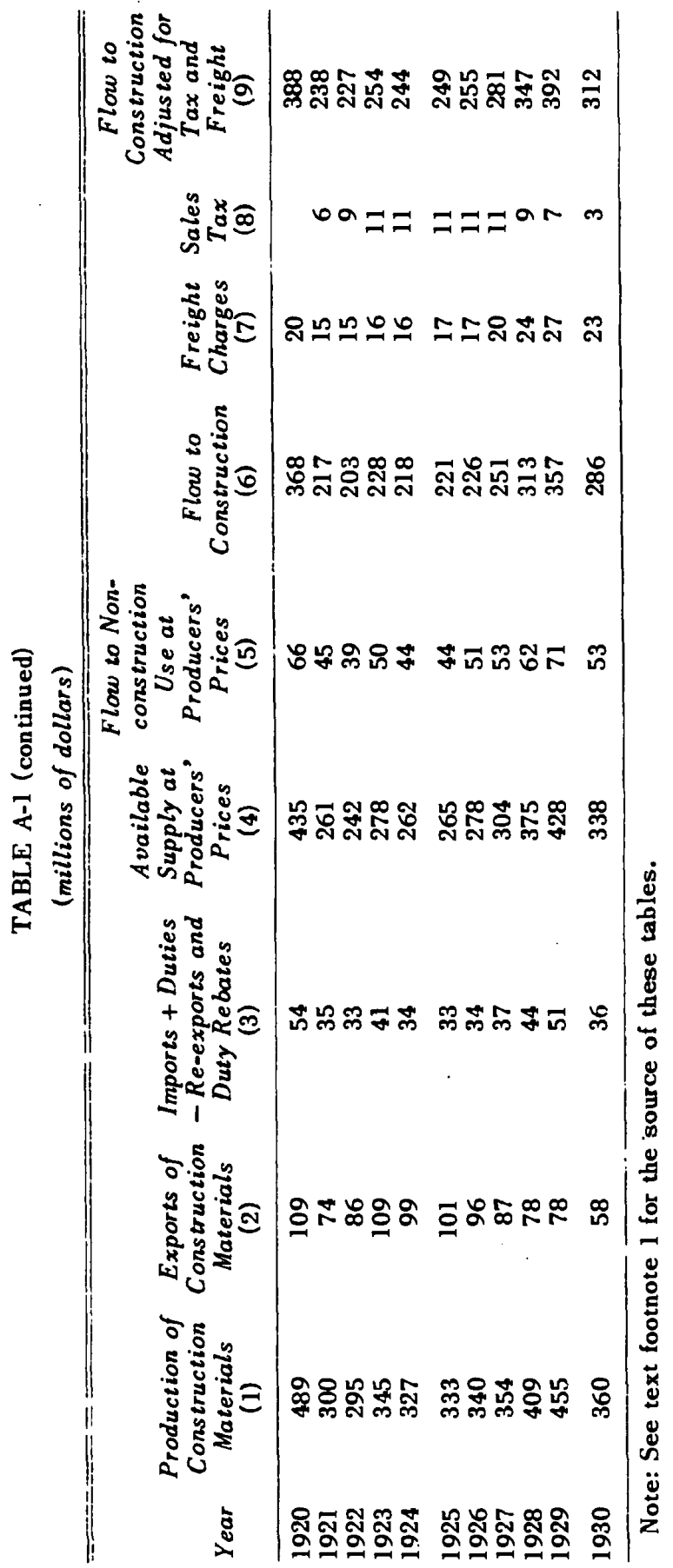


TABLE A-2

Annual Estimates of Total New and Repair Construction, Canada, 1900-1930

\begin{tabular}{|c|c|c|c|}
\hline Year & $\begin{array}{c}\text { Total Construction } \\
\text { (millions of dollars) }\end{array}$ & $\begin{array}{c}\text { Percentage of Material } \\
\text { Component }\end{array}$ & $\begin{array}{l}\text { Implicit Cost of } \\
\text { Construction Index } \\
(1913=100.0)^{\mathrm{b}}\end{array}$ \\
\hline $\begin{array}{l}1900 \\
1901 \\
1902 \\
1903 \\
1904\end{array}$ & $\begin{array}{r}119 \\
118 \\
150 \\
194 \\
220\end{array}$ & $\begin{array}{l}49.8 \\
48.7 \\
48.1 \\
47.9 \\
47.4\end{array}$ & $\begin{array}{l}66.6 \\
66.8 \\
70.1 \\
73.2 \\
74.7\end{array}$ \\
\hline $\begin{array}{l}1905 \\
1906 \\
1907 \\
1908 \\
1909\end{array}$ & $\begin{array}{l}253 \\
316 \\
360 \\
322 \\
396\end{array}$ & $\begin{array}{l}46.7 \\
47.3 \\
47.8 \\
47.1 \\
45.9\end{array}$ & $\begin{array}{l}76.9 \\
82.2 \\
86.9 \\
86.7 \\
85.7\end{array}$ \\
\hline $\begin{array}{l}1910 \\
1911 \\
1912 \\
1913 \\
1914\end{array}$ & $\begin{array}{l}453 \\
535 \\
597 \\
583 \\
480\end{array}$ & $\begin{array}{l}45.6 \\
45.1 \\
44.0 \\
44.7 \\
43.1\end{array}$ & $\begin{array}{r}88.9 \\
91.2 \\
94.4 \\
100.0 \\
97.1\end{array}$ \\
\hline $\begin{array}{l}1915 \\
1916 \\
1917 \\
1918 \\
1919\end{array}$ & $\begin{array}{l}344 \\
336 \\
464 \\
558 \\
618\end{array}$ & $\begin{array}{l}42.2 \\
44.9 \\
48.3 \\
48.4 \\
48.2\end{array}$ & $\begin{array}{r}95.7 \\
103.1 \\
120.7 \\
138.7 \\
162.2\end{array}$ \\
\hline $\begin{array}{l}1920 \\
1921 \\
1922 \\
1923 \\
1924\end{array}$ & $\begin{array}{l}986 \\
631 \\
624 \\
697 \\
692\end{array}$ & $\begin{array}{l}48.3 \\
46.2 \\
44.6 \\
44.7 \\
43.3\end{array}$ & $\begin{array}{l}198.7 \\
177.1 \\
162.4 \\
166.7 \\
164.2\end{array}$ \\
\hline $\begin{array}{l}1925 \\
1926 \\
1927 \\
1928 \\
1929\end{array}$ & $\begin{array}{r}697 \\
703 \\
783 \\
940 \\
1,046\end{array}$ & $\begin{array}{l}43.8 \\
44.3 \\
44.1 \\
45.2 \\
46.0\end{array}$ & $\begin{array}{l}161.3 \\
159.5 \\
158.8 \\
161.9 \\
167.3\end{array}$ \\
\hline 1930 & 928 & 41.3 & 165.5 \\
\hline
\end{tabular}

aThe percentage of material costs in current dollars of the estimates in col. 1. The index of material costs used was derived by linking two indexes: the Dominion Bureau of Statistics weighted index of wholesale prices of construction materials, 1913-1930, and an index devised by combining the three unweighted indexes of wholesale prices of construction materials prepared by R. H. Coats (Cost of Living Report, Ottawa, King's Printer, 1915) using weights based on the relative importance of the three groups of commodities of the domestic supply of 1908. Coats' indexes cover forty-eight commodities, 1890-1913. The index of wage rates used was the Department of Labour index of construction wage rates (Wages and Wage Rates in Canada, an annual publication of the Department of Labour).

bThe index was obtained by dividing the sum of material costs and wages in current dollars by their sum in constant dollars. 
CAPITAL FORMATION IN CANADA

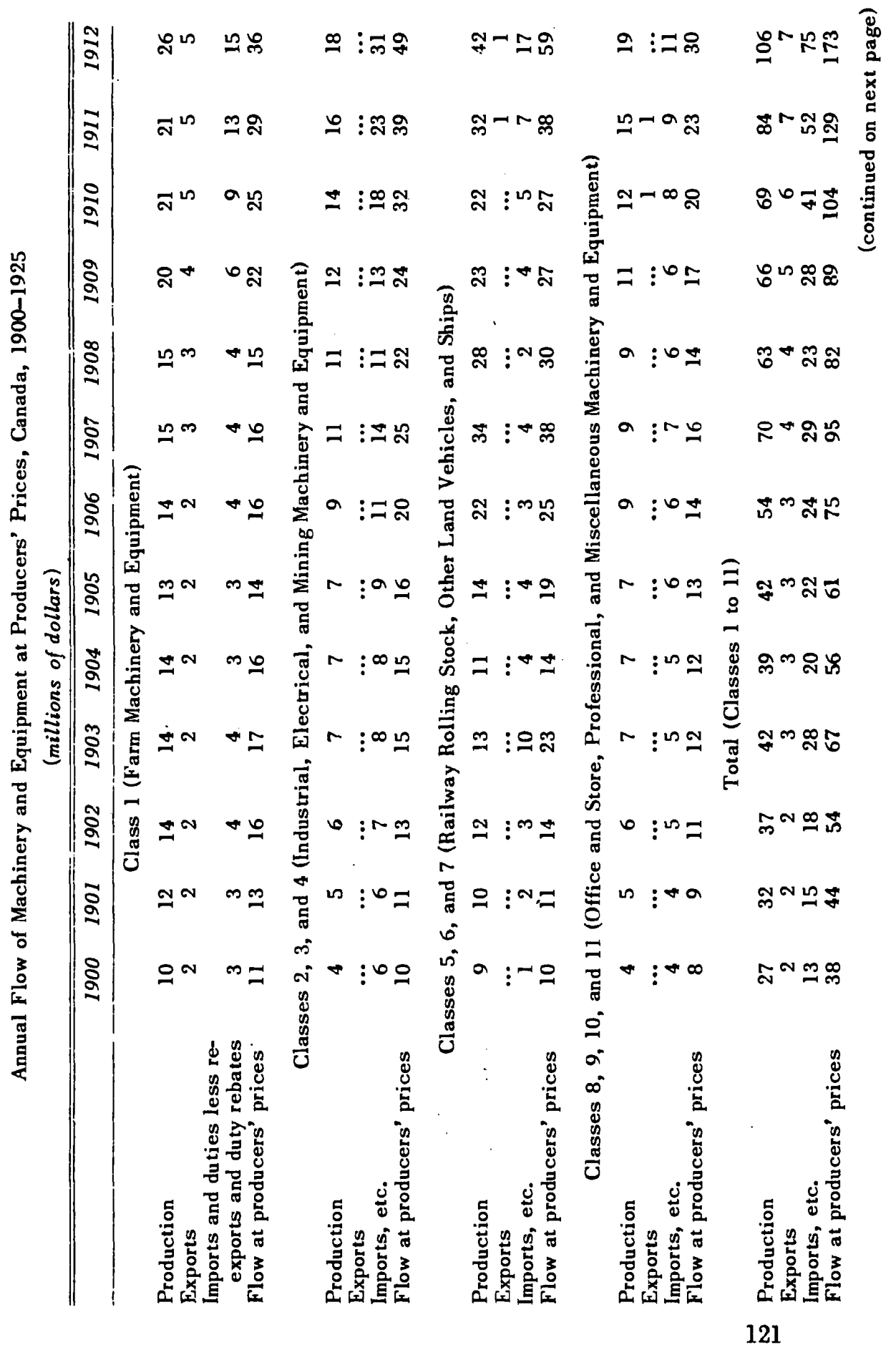


CAPITAL FORMATION IN CANADA

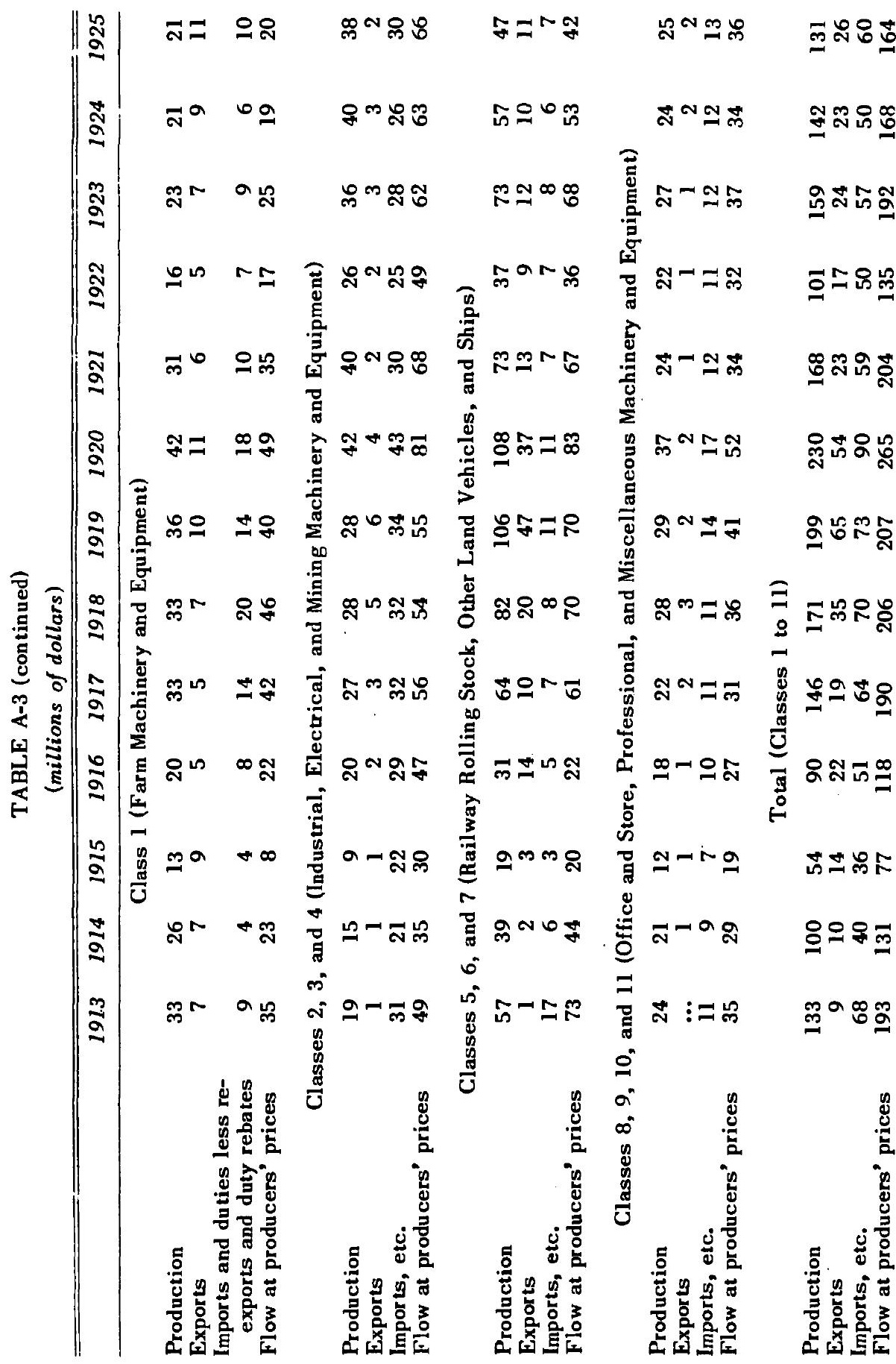




\section{CAPITAL FORMATION IN CANADA}

\section{TABLE A-4}

Quinquennial Estimates of Gross Investment in Machinery and Equipment, Canada, 1901-1930

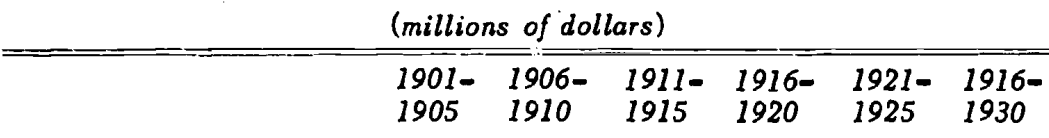

Class 1 (Farm Machinery and Equipment)

$\begin{array}{lrrrrrr}\text { Flow at producers' prices } & 76 & 94 & 131 & 199 & 116 & 207 \\ \text { Taxes } & \ldots & \ldots & \ldots ̈ & 1 & 3 & \ldots \\ \text { Freight } & 7 & 7 & 10 & 18 & 14 & 25 \\ \text { Markups } & 37 & 48 & 63 & 96 & 63 & 107 \\ \text { Gross investment } & 120 & 149 & 204 & 314 & 196 & 339\end{array}$

Classes 2, 3, and 4 (Industrial, Electrical, and Mining Machinery and Equipment)

Flow at producers' prices

Taxes

Freight

$\begin{array}{rrrrrr}69 & 124 & 202 & 293 & 308 & 576 \\ \because 3 & \cdots & \dddot{6} & 1 & 14 & 15 \\ 12 & 22 & 37 & 13 & 15 & 31 \\ 84 & 152 & 248 & 361 & 400 & 716\end{array}$

Mross investment

Classes 5 and 6 (Railway Rolling Stock and Other Land Vehicles)

$\begin{array}{lrrrrrr}\text { Flow at producers' prices } & 58 & 120 & 202 & 284 & 236 & 395 \\ \text { Taxes } & \ldots & \ldots & \ldots & 6 & 15 & 16 \\ \text { Freight } & 1 & 1 & 3 & 8 & 10 & 22 \\ \text { Markups } & 7 & 11 & 21 & 46 & 46 & 84 \\ \text { Gross investment } & 65 & 132 & 227 & 344 & 307 & 516\end{array}$

Class 7 (Ships and Boats)

$\begin{array}{lcccccc}\text { Flow at producers' prices } & 24 & 26 & 31 & 23 & 30 & 113 \\ \text { Taxes } & \ldots & \ldots & \ldots & \ldots & \ldots & \ldots \\ \text { Freight } & \ldots . & \ldots & \ldots 3 & \ldots & \ldots 3 & \ldots \\ \text { Gross investment } & 24 & 26 & 31 & 23 & 30 & 113\end{array}$

Classes 8, 9, 10, and 11 (Office and Store, Professional, and Miscellaneous Machinery and Equipment)

\begin{tabular}{|c|c|c|c|c|c|c|}
\hline $\begin{array}{l}\text { Flow at producers' prices } \\
\text { Taxes } \\
\text { Freight } \\
\text { Markups } \\
\text { Gross investment }\end{array}$ & $\begin{array}{r}56 \\
\ldots \\
3 \\
28 \\
87\end{array}$ & $\begin{array}{r}81 \\
\dddot{4} \\
42 \\
127\end{array}$ & $\begin{array}{r}136 \\
\ldots \ddot{7} \\
59 \\
202\end{array}$ & $\begin{array}{r}187 \\
1 \\
8 \\
84 \\
280\end{array}$ & $\begin{array}{r}173 \\
8 \\
9 \\
88 \\
278\end{array}$ & $\begin{array}{r}262 \\
7 \\
14 \\
131 \\
413\end{array}$ \\
\hline \multicolumn{7}{|c|}{ Total (Classes 1 to 11 ) } \\
\hline $\begin{array}{l}\text { Flow at producers' prices } \\
\text { Taxes } \\
\text { Freight } \\
\text { Markups } \\
\text { Gross investment }\end{array}$ & $\begin{array}{r}283 \\
\ddot{14} \\
84 \\
380\end{array}$ & $\begin{array}{r}445 \\
\ddot{18} \\
123 \\
586\end{array}$ & $\begin{array}{r}702 \\
\ddot{29} \\
180 \\
912\end{array}$ & $\begin{array}{r}986 \\
9 \\
47 \\
279 \\
1322\end{array}$ & $\begin{array}{r}863 \\
40 \\
48 \\
260 \\
1211\end{array}$ & $\begin{array}{r}1553 \\
38 \\
92 \\
416 \\
2097\end{array}$ \\
\hline
\end{tabular}


TABLE A-5

Quinquennial Estimates of Investment in Inventories, Canada, 1901-1930

(millions of dollars)

\begin{tabular}{|c|c|c|c|c|c|c|}
\hline & $\begin{array}{l}1901- \\
1905\end{array}$ & $\begin{array}{l}1906- \\
1910\end{array}$ & $\begin{array}{l}1911- \\
1915\end{array}$ & $\begin{array}{l}1916- \\
1920\end{array}$ & $\begin{array}{l}1921- \\
1925\end{array}$ & $\begin{array}{l}1926- \\
1930\end{array}$ \\
\hline \multicolumn{7}{|l|}{ Farm inventories } \\
\hline Livestock on farms & 100 & 63 & 112 & 98 & -3 & -46 \\
\hline Grain on farms & 18 & 23 & 168 & -18 & 20 & \\
\hline Grain in commercial channels & 10 & 5 & 65 & -43 & 101 & 50 \\
\hline \multicolumn{7}{|l|}{ Business inventories } \\
\hline Manufacturing & 61 & 95 & -27 & 260 & 14 & 621 \\
\hline Trade & 23 & 63 & 25 & 308 & 5 & \\
\hline Miscellaneous & 10 & 13 & 16 & -17 & 22 & \\
\hline Total investment & 222 & 262 & 360 & 589 & 159 & 625 \\
\hline
\end{tabular}

TABLE A-6

Annual Estimates of Gross Investment, Federal and

Provincial Governments, Canada, 1901-1930

(millions of dollars)

\begin{tabular}{|c|c|c|c|c|c|c|}
\hline \multirow[b]{2}{*}{ Year } & \multicolumn{3}{|c|}{ Federal Government } & & \multirow[b]{2}{*}{$\begin{array}{c}\text { Provincial } \\
\text { Government }\end{array}$} & \multirow[b]{2}{*}{$\begin{array}{l}\text { Total Federal } \\
\text { and Provincial }\end{array}$} \\
\hline & Railway & $\begin{array}{c}\text { Other } \\
\text { Transpor- } \\
\text { tation }\end{array}$ & $\begin{array}{l}\text { Buildings } \\
\text { and Other }\end{array}$ & Totala & & \\
\hline $\begin{array}{l}1901 \\
1902 \\
1903 \\
1904\end{array}$ & $\begin{array}{l}3.2 \\
2.7 \\
1.8 \\
3.6\end{array}$ & $\begin{array}{l}4.7 \\
5.5 \\
6.6 \\
7.5\end{array}$ & $\begin{array}{l}1.7 \\
1.3 \\
1.4 \\
2.5\end{array}$ & $\begin{array}{r}9.6 \\
9.4 \\
9.7 \\
13.6\end{array}$ & $\begin{array}{l}0.8 \\
1.2 \\
1.1 \\
0.7\end{array}$ & $\begin{array}{l}10.4 \\
10.6 \\
10.8 \\
14.3\end{array}$ \\
\hline $\begin{array}{l}1905 \\
1906 \\
1907 \\
1908 \\
1909\end{array}$ & $\begin{array}{r}3.9 \\
6.2 \\
21.0 \\
27.5 \\
21.0\end{array}$ & $\begin{array}{r}7.8 \\
5.8 \\
10.0 \\
11.2 \\
9.4\end{array}$ & $\begin{array}{l}3.5 \\
2.1 \\
3.3 \\
4.6 \\
2.7\end{array}$ & $\begin{array}{l}15.2 \\
14.1 \\
34.4 \\
43.3 \\
33.2\end{array}$ & $\begin{array}{l}0.6 \\
1.3 \\
3.0 \\
5.0 \\
5.8\end{array}$ & $\begin{array}{l}15.8 \\
15.4 \\
37.4 \\
48.3 \\
39.0\end{array}$ \\
\hline $\begin{array}{l}1910 \\
1911 \\
1912 \\
1913 \\
1914\end{array}$ & $\begin{array}{l}23.6 \\
22.4 \\
17.6 \\
20.7 \\
19.6\end{array}$ & $\begin{array}{l}11.6 \\
13.9 \\
15.1 \\
20.8 \\
24.0\end{array}$ & $\begin{array}{r}2.1 \\
3.1 \\
4.8 \\
9.2 \\
10.4\end{array}$ & $\begin{array}{l}37.3 \\
39.3 \\
37.5 \\
50.6 \\
54.0\end{array}$ & $\begin{array}{r}9.1 \\
11.2 \\
15.7 \\
19.5 \\
17.3\end{array}$ & $\begin{array}{l}46.4 \\
50.5 \\
53.2 \\
70.1 \\
71.3\end{array}$ \\
\hline $\begin{array}{l}1915 \\
1916 \\
1917 \\
1918 \\
1919\end{array}$ & $\begin{array}{r}17.6 \\
15.3 \\
9.1 \\
6.4 \\
3.8\end{array}$ & $\begin{array}{r}19.9 \\
15.0 \\
10.2 \\
6.8 \\
11.8\end{array}$ & $\begin{array}{l}5.7 \\
3.8 \\
3.4 \\
8.1 \\
9.6\end{array}$ & $\begin{array}{l}43.1 \\
34.1 \\
22.7 \\
21.3 \\
25.3\end{array}$ & $\begin{array}{r}14.5 \\
9.4 \\
6.9 \\
8.6 \\
15.8\end{array}$ & $\begin{array}{l}57.6 \\
43.5 \\
29.6 \\
29.9 \\
41.1\end{array}$ \\
\hline $\begin{array}{l}1920 \\
1921 \\
1922 \\
1923 \\
1924\end{array}$ & $\begin{array}{c}1.7 \\
1.5 \\
1.0 \\
\ldots \\
\ldots\end{array}$ & $\begin{array}{l}15.9 \\
16.0 \\
17.9 \\
22.9 \\
26.1\end{array}$ & $\begin{array}{l}5.4 \\
3.8 \\
2.0 \\
2.5 \\
5.0\end{array}$ & $\begin{array}{l}23.0 \\
21.3 \\
20.8 \\
25.4 \\
31.1\end{array}$ & $\begin{array}{l}25.0 \\
32.3 \\
30.2 \\
34.8 \\
24.8\end{array}$ & $\begin{array}{l}48.0 \\
53.6 \\
51.0 \\
60.2 \\
55.9\end{array}$ \\
\hline $\begin{array}{l}1925 \\
1926 \\
1927 \\
1928 \\
1929\end{array}$ & $\begin{array}{c}\ldots . . \\
2.7 \\
\text { n.a. } \\
\text { n.a. } \\
\text { n.a. }\end{array}$ & $\begin{array}{l}26.9 \\
22.8 \\
\text { n.a. } \\
\text { n.a. } \\
\text { n.a. }\end{array}$ & $\begin{array}{c}4.9 \\
3.1 \\
\text { n.a. } \\
\text { n.a. } \\
\text { n.a. }\end{array}$ & $\begin{array}{l}31.7 \\
28.6 \\
36.9 \\
40.2 \\
45.9\end{array}$ & $\begin{array}{l}26.6 \\
24.1 \\
31.6 \\
41.2 \\
51.5\end{array}$ & $\begin{array}{l}58.3 \\
52.7 \\
68.5 \\
81.4 \\
97.4\end{array}$ \\
\hline 1930 & n.a. & n.a. & n.a. & 63.2 & 67.7 & 130.9 \\
\hline
\end{tabular}




\section{Notes to Table A-6}

apefinitions, sources, and general procedures were derived from those employed in Public Investment and Capital Formation, A Study of Public and Private Investment Outlay, Canada, 1926-1941, Ottawa, King's Printer, 1945 (P.I.C.F.). The official estimates covered investment and repair expenditures on construction, resource development, and machinery and equipment. A considerable proportion of these are charges by the government to current account and many items included in government capital expenditures are not investment in the economic sense (see P.I.C.F., pp. 12-19, for a discussion of the "public finance" and "national income" approaches to public expenditure). However, the records of annual expenditures available in the Auditor General's Reports are sufficiently detailed to allow the appropriate reclassifications.

For the present study the examination of annual Auditor General's Reports was limited to the four federal departments most active in the construction field: public works, railways and canals, marine and fisheries, and, although less important than the others, trade and commerce. In 1926 these departments accounted for $\$ 27.1$ million of the total new construction outlay by the federal government of $\$ 28.6$ million, that is, for 94.6 per cent of the total reported in P.I.C.F.

The official estimates published in P.I.C.F. were made for six spot years from 1926 to 1941 by an examination of each item of expenditure shown in the detailed Reports. Such care was neither practicable nor warranted for the present study. However, since the estimates were made for each year from 1900 to 1926 , the present estimates are consistent over the whole period. The reconciliation with the official estimates for 1926 shows a remarkably close agreement. For that year the present estimate of new construction by the four major departments is $\$ 26.5$ million, which is $\$ 0.6$ million or less than 2 per cent below the P.I.C.F. estimate for the same departments, and 7.3 per cent below the official estimate for all new construction. The $\$ 2.1$ million difference was run back, as miscellaneous construction, on an index of federal building construction.

No effort was made to measure federal expenditures on machinery and equipment other than railway equipment. The total of other machinery in 1926 was $\$ 3.8$ million, which includes certain duplications already covered in construction (cf. P.I.C.F., p. 116). Important elements in this expenditure were automobiles and office machinery and equipment, and both, especially automobiles, would be less important in the earlier years. Another excluded item is investment in resource development (reforestation, topographical surveys, etc.), which accounted for $\$ 1$ million of federal investment in 1926. Again, some part of this was duplicated in construction and therefore covered. The pattern of government construction in the twenty-five years under review was heavily weighted by railway construction before World War I. The peak values in 1913 and 1914 was twice the 1926 expenditure. The expenditures on machinery and equipment and resource development would not follow this pattern. Since they could hardly reach a million dollars in the pre-1920 era, it was safe to ignore them.

bAgain the pattern established by P.I.C.F. was followed. The most careful attention was given to highways, which predominate in provincial investment. The rapid emergence of the automobile during World War I raised provincial investment from relatively low levels before the war to levels comparable to federal expenditures during the 1929's.

The general method was to make an estimate for 1926 from the Public Accounts of the provinces that conformed as closely as possible with the P.I.C.F. estimate, and to make comparable estimates for several spot years 


\section{Notes to Table A-6 (continued)}

and fill in the intervening years with appropriate interpolators. Annual series on highway expenditures were obtained for all provinces except Manitoba and the Maritimes. These were reliable total series, but while in some (for example, the estimates prepared for the Ontario Royal Commission on Transportation, Toronto, Government of Ontario, 1938) the distinction between new and repair was sound, in others this necessary breakdown was more or less arbitrary.

The present highway estimate for 1926 checked precisely at $\$ 31.2$ million with the P.I.C.F. estimate for that year. The differences by provinces did not exceed $\$ 0.1$ million. The smaller investment in public buildings of $\$ 3.4$ million also checked closely with the official estimate for 1926 .

n.a. = breakdown not available.

... indicates less than 00 .

TABLE A-7

Annual Estimates of Gross Investment and Repair, Steam Railways, Canada, 1896-1930

(millions of dollars)

\begin{tabular}{|c|c|c|c|c|c|c|}
\hline \multirow[b]{3}{*}{ Year } & \multicolumn{2}{|c|}{ Road Construction } & \multirow{2}{*}{\multicolumn{2}{|c|}{ Equipment }} & \multirow{2}{*}{1} & \multirow{3}{*}{$\begin{array}{l}\text { Gross Investment } \\
\text { and Repair }\end{array}$} \\
\hline & & Replacement $\mathbf{b}$ & & & & \\
\hline & $N e t^{a}$ & and Repair & Net $\mathrm{a}$ & Replacement & Repair & \\
\hline $\begin{array}{l}1896 \\
1897 \\
1898 \\
1899\end{array}$ & $\begin{array}{r}3.2 \\
6.4 \\
12.6 \\
8.4\end{array}$ & $\begin{array}{l}8.1 \\
7.8 \\
8.3 \\
9.3\end{array}$ & $\begin{array}{l}0.9 \\
1.4 \\
2.9 \\
3.9\end{array}$ & $\begin{array}{l}0.6 \\
0.6 \\
0.7 \\
0.8\end{array}$ & $\begin{array}{l}5.6 \\
5.8 \\
6.2 \\
7.1\end{array}$ & $\begin{array}{l}18.4 \\
22.0 \\
30.7 \\
29.5\end{array}$ \\
\hline $\begin{array}{l}1900 \\
1901 \\
1902 \\
1903 \\
1904\end{array}$ & $\begin{array}{l}11.4 \\
12.6 \\
12.4 \\
19.2 \\
25.0\end{array}$ & $\begin{array}{l}10.3 \\
11.7 \\
13.8 \\
14.7 \\
16.1\end{array}$ & $\begin{array}{l}3.4 \\
4.6 \\
6.6 \\
8.2 \\
6.3\end{array}$ & $\begin{array}{l}0.9 \\
1.0 \\
1.2 \\
1.4 \\
1.5\end{array}$ & $\begin{array}{r}8.1 \\
9.0 \\
10.6 \\
12.4 \\
12.4\end{array}$ & $\begin{array}{l}34.1 \\
38.9 \\
44.6 \\
55.9 \\
61.3\end{array}$ \\
\hline $\begin{array}{l}1905 \\
1906 \\
1907 \\
1908 \\
1909\end{array}$ & $\begin{array}{l}33.0 \\
42.5 \\
72.2 \\
75.5 \\
69.6\end{array}$ & $\begin{array}{l}17.4 \\
19.1 \\
19.6 \\
19.8 \\
23.9\end{array}$ & $\begin{array}{r}8.5 \\
13.3 \\
23.8 \\
18.7 \\
14.8\end{array}$ & $\begin{array}{l}1.6 \\
1.9 \\
2.0 \\
2.9 \\
1.3\end{array}$ & $\begin{array}{l}14.7 \\
17.3 \\
18.9 \\
18.1 \\
21.4\end{array}$ & $\begin{array}{r}75.2 \\
94.1 \\
136.5 \\
135.0 \\
131.0\end{array}$ \\
\hline $\begin{array}{l}1910 \\
1911 \\
1912 \\
1913 \\
1914\end{array}$ & $\begin{array}{r}88.1 \\
93.4 \\
110.3 \\
115.7 \\
91.9\end{array}$ & $\begin{array}{l}26.9 \\
29.1 \\
32.8 \\
34.1 \\
29.8\end{array}$ & $\begin{array}{l}11.8 \\
20.4 \\
34.1 \\
46.7 \\
23.1\end{array}$ & $\begin{array}{l}1.5 \\
2.7 \\
2.8 \\
2.8 \\
2.7\end{array}$ & $\begin{array}{l}23.3 \\
25.1 \\
30.2 \\
33.1 \\
29.5\end{array}$ & $\begin{array}{l}151.6 \\
170.7 \\
210.2 \\
232.4 \\
177.0\end{array}$ \\
\hline $\begin{array}{l}1915 \\
1916 \\
1917 \\
1918 \\
1919\end{array}$ & $\begin{array}{l}78.9 \\
29.7 \\
27.1 \\
26.6 \\
32.4\end{array}$ & $\begin{array}{l}31.5 \\
36.5 \\
44.3 \\
59.9 \\
79.0\end{array}$ & $\begin{array}{r}7.9 \\
6.4 \\
28.9 \\
37.1 \\
31.5\end{array}$ & $\begin{array}{l}1.5 \\
2.0 \\
6.8 \\
4.9 \\
7.6\end{array}$ & $\begin{array}{l}28.5 \\
35.4 \\
45.9 \\
69.5 \\
79.2\end{array}$ & $\begin{array}{l}148.3 \\
110.0 \\
153.0 \\
198.0 \\
229.7\end{array}$ \\
\hline $\begin{array}{l}1920 \\
1921 \\
1922 \\
1923 \\
1924\end{array}$ & $\begin{array}{l}42.3 \\
33.2 \\
15.0 \\
35.0 \\
32.1\end{array}$ & $\begin{array}{l}94.7 \\
84.9 \\
76.6 \\
78.4 \\
74.0\end{array}$ & $\begin{array}{r}36.6 \\
37.7 \\
6.2 \\
30.1 \\
19.1\end{array}$ & $\begin{array}{r}8.3 \\
2.7 \\
6.1 \\
13.4 \\
9.1\end{array}$ & $\begin{array}{r}107.3 \\
87.7 \\
83.7 \\
86.1 \\
77.9\end{array}$ & $\begin{array}{l}289.2 \\
246.2 \\
187.6 \\
243.0 \\
212.2\end{array}$ \\
\hline $\begin{array}{l}1925 \\
1926 \\
1927 \\
1928 \\
1929\end{array}$ & $\begin{array}{l}22.6 \\
30.5 \\
39.3 \\
55.4 \\
79.1\end{array}$ & $\begin{array}{l}70.4 \\
76.4 \\
82.2 \\
93.5 \\
89.4\end{array}$ & $\begin{array}{r}2.8 \\
14.1 \\
30.9 \\
12.4 \\
55.4\end{array}$ & $\begin{array}{l}5.6 \\
7.8 \\
8.3 \\
9.5 \\
9.1\end{array}$ & $\begin{array}{l}77.3 \\
82.9 \\
84.4 \\
91.3 \\
89.9\end{array}$ & $\begin{array}{l}178.7 \\
211.7 \\
245.1 \\
262.1 \\
322.9\end{array}$ \\
\hline 1930 & 53.2 & 74.3 & 32.8 & 13.7 & 67.6 & 241.6 \\
\hline
\end{tabular}


Notes to Table A-7

aThis is "net" as the railways use the term.

bA reliable breakdown of this component on an annual basis has not been made.

cGovernment investment in railways is included in the estimates.

Note: The estimates cover gross investment and repair expenditures of steam railways, excluding inventories, with a breakdown between road construction and rolling stock. Detailed estimates of this kind are available for 1926-1930 in P.I.C.F. Annual records of the two maintenance accounts-ways and structures and equipment-appears in DBS publications beginning in 1920 and in Sessional Papers for the earlier years. 'These records are given in sufficient detail for most of the period to permit the subtraction of certain items which are neither replacement nor repair. A sound breakdown of replacement charges and repair for the equipment account was made and the former adjusted from "a charge" to "an expenditure" basis. An approximation of the same breakdown was achieved for the road account. The determination of the new investment expenditures, ile. "net" in the railways' use of the term, offered greater difficulty.

In 1926 there were two large systems, the Canadian Pacific (C.P.R.) and the Canadian National (C.N.R.), accounting for 91 per cent of the total mileage, and a group of minor roads. The history of the lines was examined and the status of the constituents of the major systems was established for each year back to 1895 . Only two of the minor roads, the Temiskaming and Northern Ontario (T.N.O.) and the Pacific Great Eastern (P.G.E.), were covered. Provincial records provided most of the data for these two minor lines. The C.P.R. of fered little difficulty. Its expenditures on road and equipment have been published in fair detail in annual reports. (A great deal of additional data are now available in exhibits and other submissions made during recent railway rate cases. These were used to check the estimates.) Similar detail on the C.N.R. has been published since 1923. The C.N.R. report for that year covered several major groups - the Grand Trunk and the Grand Trunk Pacific, the Canadian Northern system, and the government railways group including the National Transcontinental. The last two groups were combined for coordinated operation in the closing months of 1918. The Grand Trunk Pacific, including the Saskatchewan Branch Lines Co. (G.T.P.), was added in September 1920. The Grand Trunk (G.T.), which had been acquired by the federal government in 1920, was added in 1922. Thus the C.N.R. emerged in a "period of transition" from 1917 to 1922 . The total expenditures during this period were not too difficult to determine and the total was allocated to the different years with the help of Auditor General's Reports, federal Public Accounts, annual reports of the companies, and several monographs and official documents on Canadian railways.

The annual expenditures of the G.T. were adequately reported in the company's reports back to 1895 . The required data for the government railways group appear in Auditor General's Reports. There remained only the G.T.P. and the Canadian Northern system. Reports on the former were never published and the annual reports of the latter were unreliable.

The total actual expenditure on the construction of the G.T.P. from 1903 to 1917 is a matter of public record since certified costs were reported by the G.T. to the government during construction. Noninvestment costs, e.g. the large interest payments during construction, were easily eliminated from the itemized account of the cost. The following technique was employed to distribute the total cost to appropriate years. There was an independent estimate of the cost of the road prepared by a group of engineers 


\section{Notes to Table A-7 (continued)}

under the direction of Swain for the Royal Commission on Railways and Transportation, 1917. Swain's report gives complete details of the estimates for each section of the G.T.P. and Saskatchewan Branch Lines. A complete history of the road was worked out from various sources and the dates of beginning and completion of each section were tabled chronologically. Swain's cost data were then applied to secure an index of annual construction appropriately weighted for the wide variations in cost in different parts of the country. The index was used to distribute the total investment over the years.

The Canadian Northern was made up of over twenty lines. The DraytonAcworth Commission determined the total receipts of cash by sources for all these companies and accounted for its disposition by types of expenditure. The total expenditure on road, terminals, and equipment was established in these data. The ratio of equipment investment to total investment in additional studies by Swain and Buchannan provided the required breakdown. This left only the problem of distributing totals to appropriate years from 1896 to 1917 . The method used rests on the assumption that annual cash outlay on road and equipment must have varied closely with annual cash inflow. From various official and private sources, the annual cash inflow from security sales (less discountsl, equipment trust certificates, net proceeds of land sales, short-term loans, government advances (when not reflected in bonded liabilities), and cash subsidies was determined for the group as a whole. A three-year moving average of a two-year moving average of this series was taken to interpolate from June fiscal to calendar years and to smooth the series. An index of this series was then used to allocate the total investment to years and, in the first approximation, equipment expenditures were taken as a constant ratio of the total. Then an index based on annual changes of the numbers of rolling stock (the different types were weighted with their relative prices in the early 1920's) was used to redistribute the equipment expenditures and achieve the final adjustment between road and equipment investment in each year.

\section{TABLE A-8}

Rough Estimates of Gross National Product, Canada, 1901-1930

(millions of dollars)

\begin{tabular}{|c|c|}
\hline Period & Gross National Product \\
\hline $\begin{array}{l}1901-1905 \\
1906-1910 \\
1911-1915 \\
1916-1920 \\
1921-1925 \\
1826-1930\end{array}$ & $\begin{array}{l}5,634 \\
8,916 \\
13,235 \\
22,493 \\
22,584 \\
28,758 \text { a }\end{array}$ \\
\hline
\end{tabular}

aThe total for 1926-1930 is from National Accounts, Income and Ex penditure, Ottawa, Dominion Bureau of Statistics, appropriate years.

Note: The approximate levels of GNP from 1901 to 1930 were established in the following way. The new DBS series began with the year 1926. A reliable series, prepared by D. C. MacGregor for the Bank of Nova Scotia, is available for the period 1921-1930 (Monthly Review, Bank of Nova Scotia, May 1937). J. J. Deutsch published an admittedly rougher series for the period 1911-1920 (J. J. Deutsch, "War Finance and the Canadian Economy," Canadian Journal of Economics and Political Science, November 1940, pp. 538-539). Both series used the same general 
Notes to Table A-8 (continued)

method: estimating value added by each branch of primary and secondary industries on the basis of DBS and other federal records and estimating the tertiary component with a sample series including railways, government, and certain service industries. There is no apparent inconsistency in the adjacent terminal estimates (1920 and 1921) for the primary and secondary components of the two series, but the level of the tertiary component of the earlier series was too low. It was extended to 1921 on an index of the change from 1920 to 1921 in the tertiary component of the old DBS national income series (Canada Year Book, 1943-44, Ottawa, DBS, 1944 , p. 800) and used to extrapolate the MacGregor estimate for the tertiary component from 1921 to 1911. Depreciation was included by the methods employed by both writers. Certain adjustments were required to make the series conform conceptually with GNP: (1) deduct investment income paid abroad; (2) add investment income from abroad (these have been estimated from 1900 to 1930 by F. A. Knox); (3) add indirect taxes less subsidies. A sample for (3) covering 72 per cent of the total in 1926 was available over the period. The net values added by the construction industry in both the MacGregor and Deutsch series were based on MacLean's contracts awarded. The present estimates of construction provide a bet ter basis for this purpose, and the net-value-added series for construction was adjusted accordingly.

An estimate was made of income produced in 1900 following Deutsch's method and similarly adjusted to a GNP basis. The adjusted series for 1900 and 1911-1930 inclusive was used as an index to extrapolate the official estimates of GNP to 1911 and to 1900 .

The years 1901-1910 were interpolated on the basis of the relationship between the estimated GNP in 1900 and 1911 and the volume of the money supply (cash in the hands of the public plus total domestic deposits: annual averages of month-end figures).

The GNP figures differ from the estimates used in my Capital Formation in Canada, 1896-1930 (University of Toronto Press, 1955, pp. 11 and 63). I used the old DBS series to adjust the tertiary component in the present series after being convinced that my initial judgment of the extent of the downward bias in Deutsch's tertiary component was wrong.

\section{COMMENT}

\section{Penelope Hartinan, National Bureau of Economic Research}

Compliments are due Kenneth Buckley for amassing a multitude of facts (part of which relates to an era that in terms of economic records is almost prehistoric) and for adjusting and combining them into a meaningful whole. The results of his labors are especially interesting because during the period he studied, Canada experienced the first really sizable and rapid economic expansion since Confederation. In the first decade of the twentieth century $\$ 1.2$ billion of foreign capital flowed into Canada; ${ }^{1}$ before 1914

'This is computed from Jacob Viner's data in Canada's Balance of International Indebtedness, 1900-1913 (Harvard University Press, 1924) and includes only actual gold exports, not gold production. 


\section{CAPITAL FORMATION IN CANADA}

about 2 million immigrants entered the country. ${ }^{2}$ By comparison only $\$ 500$ million of foreign capital was invested in Canada during the 1890's and emigration was larger than immigration. ${ }^{3}$ Because of the importance of foreign capital in the total measure of Canadian gross domestic investment before 1915, I should like to confine my remarks to the foreign investment component of capital formation.

The definition of capital formation adopted by Buckley is one used for earlier official estimates. It relates to a flow of certain types of goods to certain users in Canada. In Table 1, lines 1-4 represent the total and components of this flow to Canadian users from all sources, domestic and foreign. Lines 5 and 6 answer the question: How much of the total capital formation has been provided by foreign sources? The answer, of course, must depend on what is meant by foreign investment in relation to capital formation. Given the original definition of capital formation, the foreign contribution to it could vary in magnitude from a figure measuring solely the inflow of the specified goods from abroad through one measuring the total import-content of these goods, to a measure of the balance between total receipts from and payments to the rest of the world for all current transactions. The last measure, and the most inclusive, is used here: by foreign investment is meant the net change in the claims of foreigners against Canada resulting from all transactions in the period.

Since the purpose of line 5 of Table 1 is to measure the contribution of the rest of the world to Canadian capital formation in these years, it would seem desirable to depart from the balance of payments treatment of monetary and nonmonetary gold and to describe changes in the monetary gold stock as another component of gross investment. If there is any advantage in limiting the number of components, as is implied in the text, changes in the gold stock could be incorporated within the inventory group.

In official Canadian balance of payments estimates, a purchase of domestically mined gold for monetary stock is entered as an export of nonmonetary gold in the current account and as an import of monetary gold (an increase of gold and dollar reserves) in the

${ }^{2}$ Computed from ibid., pp. 57-58, gross inflow.

'Preliminary estimates made by the author.

the "gross addition to all finished durable physical commodities in the hands of producers, gross residential construction and the net changes in stocks in the hands of producers" (P.I.C.F., p.l). 
capital account. While this practice serves the balance of payments purpose well, it can distort the relative contributions of both domestic and foreign sources to capital formation, and the absolute level of such activity if carried into capital formation estimates. Both the debit balance on current account and gross domestic investment in line 4 can be made smaller by such treatment. For example, during the years 1901-1905, the current account balance excluding all gold was $\$ 377$ million; ${ }^{\circ}$ as compared with the figure of $\$ 301$ million presented by Buckley. This implies that over $\$ 70$ million of gold was purchased for monetary stock and therefore treated as an export during these years. (Actually Buckley also corrected the tourist account so that the $\$ 76$ million difference also contains the effects of that adjustment. The tourist balance, however, is small by comparison.') In recent years all current gold production has been purchased for monetary stock with the exception of small amounts used in the arts. It is possible that, in any given year, all the current gold output would be exported and the net claims of foreigners against Canada thereby reduced de facto. But insofar as this is not true, the increase in gold inventories represents only a potential counterclaim against the rest of the world, not one that has actually been exercised in international transactions. Thus in 1901-1905 the debit balance may be understated by 25 per cent or more, and inventory accumulation and gross domestic investment by the same absolute amount. Line 6, of course, would not be changed, but under these conditions, it would comprise a smaller proportion of line 4 than is now the case.

Measuring the contribution of the rest of the world to capital formation in Canada in terms of the Canadian estimate of its net balance of payments on current account means, further, that there are included in line 5 two types of transfer payments: the contributions of individuals and institutions to foreigners and the capital of migrating settlers. For the years 1901-1905 the Canadian balance of payments includes an estimate of $\$ 90$ million brought into

- Canadian Balance of International Payments, A Study of Methods and Results, Ottawa, Dominion Bureau of Statistics, 1939, pp. 60-61; also, The Canadian Balance of International Payments, 1926-1948, Ottawa, DBS., 1949, pp. 111-114. This treatment is recommended by the International Monetary Fund in its Balance of Payments Manual, 1950.

- Computed from F. A. Knox, Dominion Monetary Policy, 1929-1934, Ottawa, a study prepared for the Royal Commission on Dominion-Provincial Relations, 1939, p. 92 . Including actual gold trade the current account balance was $\$ 314$ million.

'lbid., pp. 89-90. 
Canada by immigrants, $\$ 25$ million taken out by emigrants, or a net credit balance of $\$ 65$ million. $^{8}$ By comparison, in the United States balance of payments, estimates of personal remittances attempt to exclude transfers of capital although the money carried on their persons by alien immigrants is included. ${ }^{\circ}$ There is no separate entry for migrants' capital.

Although neither of these transfer payments arises from the current production of goods and services in Canada or the rest of the world, each affects the net claims of foreigners against Canada. Only if interest in capital formation should center in the contributions of current output alone would it be appropriate to omit these unilateral transfers from the measure of foreign investment. On the other hand they might be so large in certain cases as to warrant separate statement in the capital formation estimates. For the years 1901-1905 the credit balance from immigrants' capital was partially counteracted by a net outflow of personal remittances so that these unilateral transfers together accounted for a net credit balance of $\$ 35$ million.

This debit balance of payments on current account, when used in a measure of capital formation, represents essentially the volume of foreign savings from past and current output which has contributed to the formation of this volume of capital in Canada and the levels of consumption actually achieved there at the same time. If then the attempt is to be made to measure the relative contributions of domestic and foreign savings to capital formation, it would seem preferable to use the measure of capital formation itself to represent gross savings rather than to shift to the national income concept of savings as is done in Table 3. Gross saving is defined in Canadian national income accounting and in our own as equal to private investment plus the combined government deficit. Since public investment in capital formation may be greater or less than the deficit, it may not only be misleading but also may omit useful information to shift to the national income measure of saving. The shift is accomplished by deducting public investment from gross domestic investment (line 4 of Table 1) and substituting the deficit. After deducting foreign investment one arrives at the national income measure of gross saving.

${ }^{8}$ Computed from Viner, op. cit., pp. 57-58.

'United States in the World Economy, Dept. of Commerce, Economic Series No. 23, 1940, p. 77. 
There is nothing conceptually incompatible between this measure of capital formation and the usual measure of GNP. A comparison of the two assumes that, within the government sector of national expenditures, expenditures resulting in capital formation have been separated out and appropriate adjustments have been made in the saving account. Thus in comparing gross capital formation (line $6=$ gross domestic saving according to capital formation definition) with the estimates of GNP for the same periods, about the same constancy of domestic savings appears as Buckley observed in Table 3. Moreover the distortion of the savings rate which he observed during the years 1916-1920 because of the great increase in the government deficit disappears. With one exception, the ratios of gross capital formation (line 6, Table 1) to GNP in these periods do not vary by as much as 2 per cent. The lower level of the ratio in $1911-1915,14.5$ per cent as compared with 17.7 for the preceding period and 18.0 for the succeeding period, is the result of a low rate of domestic savings and capital formation with a very large inflow of capital from abroad.

\begin{tabular}{|c|c|c|c|}
\hline \multirow[b]{2}{*}{ Period } & \multirow{2}{*}{$\begin{array}{l}\text { Ratio of Gross } \\
\text { Capital Formation } \\
\text { (line } 6 \text { of Table } 1 \\
\text { to GNP of Table A-8) }\end{array}$} & \multicolumn{2}{|c|}{ Ratio of Foreign to Domestic Saving: } \\
\hline & & $\begin{array}{c}\text { Capital } \\
\text { Formation } \\
\text { Definition }\end{array}$ & $\begin{array}{c}\text { National } \\
\text { Income } \\
\text { Definition b }\end{array}$ \\
\hline $\begin{array}{l}1901-1905 \\
1906-1910 \\
1911-1915 \\
1916-1920 \\
1921-1925 \\
1926-1930\end{array}$ & $\begin{array}{l}17.4 \\
17.7 \\
14.5 \\
18.0 \\
16.4 \\
18.3\end{array}$ & $\begin{array}{r}31 \\
52 \\
86 \\
7 \\
2 \\
11\end{array}$ & $\begin{array}{r}32 \\
51 \\
72 \\
5 \\
2 \\
11\end{array}$ \\
\hline
\end{tabular}

a Table 1 , line 5 divided by line 6 .

bTable 3 , col. 3 divided by col. 4 .

Moreover in comparing the relative contribution of foreign and domestic saving to capital formation, very different results can be obtained depending on whether the national income or capital formation definition of gross domestic saving is used. For example for the period 1911-1915, if one uses the capital formation definition of saving, foreign saving amounted to 86 per cent of domestic; on the other hand the national income definition results in a ratio of foreign to domestic savings of 72 per cent. For the other periods the two definitions yield ratios which are either identical or very close. 


\section{CAPITAL FORMATION IN CANADA}

\section{H. Jones, Canadian Bureau of Statistics}

As the sole representative here of the Canadian Bureau of Statistics, I appreciate the opportunity of making a few comments on Kenneth Buckley's paper. As 0. J. Firestone has noted, the investment estimates appearing in Private and Public Investment are incorporated, with certain conceptual adjustments, in the official estimates of gross national expenditure prepared by the Bureau. Prior to the completion of the P.P.I. study, we had been using the estimates appearing in the earlier study Public Investment and Capital Formation. Consequently we are keenly interested in Buckley's suggestion that the first estimates may be superior in certain respects to the later, revised estimates.

We are very glad to have this type of criticism. It is scarcely necessary to note that the official national accounts estimators in the United States and the United Kingdom have benefited enormously from criticism, suggestions, and research originating from nonofficial sources, in particular the universities and private research organizations. In Canada we have in the past benefited from the work of D. C. MacGregor of the University of Toronto. On the whole, however, we have not succeeded in arousing the interest of the academic world in national accounts problems to the extent that we would like.

Since Buckley's criticism of the investment estimates involves the question of the accuracy of the "corporation sample" (a sample study of corporation revenues, expenditures, and balance sheet items in the period 1926-1946), I should like to comment on this first. As Firestone notes, other components of the national accounts, such as inventory change, depreciation, and corporation profits, are also based in varying degrees on the results of this sample study. The question arises then that if there is a bias in the machinery investment estimates derived from this sample, does it follow that there is also a bias in the other series derived from the same sample? There are a number of reasons for supposing that it does not. Errors in estimates derived from survey data may arise from many causes other than flaws in the basic sample design. In the particular case under discussion, the following observations are relevant.

1. Because the basic source of the data was income tax records, one would expect greater intrinsic accuracy in some items than in others, depending on their relevance to the main purpose of the reports, i.e. assessing taxes. 
2. Some items would furnish less satisfactory characteristics for sampling purposes than others, depending on the regularity of their occurrence from firm to firm and year to year. With a fixed sample, the variance and therefore the statistical precision would not be the same for each item.

3. The adjustments made in the basic data were considerably more complex for some items than for others. In the case of investment, for instance, adjustments were especially complex, involving separation of used goods from new goods, distinguishing machinery from construction, and allowing for investment by unincorporated concerns. On the whole we feel that evidence of bias in the investment series would not necessarily imply a similar bias in other series derived from the same sample.

I would like now to turn to the question: Is there a bias in the revised estimate of investment in machinery and equipment? In the case of manufacturing companies, the list from which the sample was drawn was based on two separate lists, one of companies existing in 1926 and the other of those existing in 1946. Thus there should be no bias in favor of the "stronger" companies as Buckley suggests. In any event such a bias would be operating in the wrong direction to explain the higher level of the revised series in the earlier period.

Naturally the Dominion Bureau of Statistics examined the two versions of the investment series before deciding to incorporate the revised series in the national accounts. The investigation was perhaps not as thorough as it might have been, owing to a problem in timing. The completion of the revised investment estimates was uncomfortably close to a deadline, set sometime previously, for completing the revised national accounts estimates. However, analysis of the two versions of the investment series in the context of the accounts tended to confirm the revised series.

Like a number of other countries, the Bureau computes substantially independent estimates of gross national product and gross national expenditure. Where two versions of a component series are being compared, the balancing nature of the accounts enables us to compute a third, independent "test" series to help in deciding on the relative merits of the two direct estimates. This is done by subtracting, from the unadjusted GNP, the components of GNE, other than the series to be tested (investment in machinery and equipment, in this instance). The test series in this case tend to confirm the revised investment estimate. If the three series are plotted, it is readily seen that the revised investment esti- 


\section{CAPITAL FORMATION IN CANADA}

mate agrees, on the whole, most closely with the test series. This agreement is confirmed arithmetically by a comparison of the mean absolute annual difference between the test series and each version of the direct estimate. The mean absolute difference is substantially lower in the case of the revised series.

On the whole, however, we feel that Buckley's remarks are sufficiently acute and well documented to warrant some further investigation. Since we will in the near future be remexamining the historical national accounts series in the light of new data becoming available from a comprehensive census of population, housing, and distribution taken in 1951, this will be an appropriate time to review the investment series in the light of his findings. In particular we will explore the question of whether a probable bias in the estimates of investment in the industry group "food and beverages" would imply a similar bias in the "all industry" totals, or whether, for statistical reasons, we would expect greater accuracy in the larger aggregate.

O. J. Firestone, Economic Adviser, Canadian Department of Trade and Commerce, Ottawa

Kenneth Buckley has done a very useful service in assembling for this Conference a series on capital formation in Canada-the official estimates from 1926 to date and his personal estimates back to 1900 . He is eminently well qualified for this job. He was one of the original group of research people who helped my colleague, M. C. Urquhart, and myself prepare the report, Public lnvestment and Capital Formation, A Study of Public and Private Investment Outlay, Canada, 1926-1941, ${ }^{1}$ for the DominionProvincial Conference on Reconstruction, August 1945. In fact I gather that it was Buckley's interest in this assignment and some work he did subsequently for us on Residential Real Estate in Canada ${ }^{2}$ that induced him to choose the topic, Real Investment in Canada, 1900-1930, as the subject for his doctoral thes is for the London School of Economics. It appears that the paper before us is based largely on his thesis, which he completed in 1950.

Buckley prepared his estimates of capital formation for the period 1900-1930 following the techniques developed in the study, Public Investment and Capital Formation, which was published

${ }^{1}$ Ottawa, King's Printer, 1945 (P.I.C.F.).

${ }^{2} \mathrm{O}$. J. Firestone, Residential Real Estate in Canada, University of Toronto Press, 1951. 
in 1945. He used a similar concept. Therefore anyone wanting to use a comparable series would do well, as Buckley suggests, to use his series linked with the data shown in the study, P.I.C.F. Up to 1950 the data in the latter study were the official estimates of capital formation in Canada, and they were incorporated, with some adjustments, in the official estimates of the national accounts published by the Dominion Bureau of Statistics.

In 1951, after five years of further development work, the Department of Trade and Commerce published a study analyzing investment behavior in Canada. This report includes revised estimates of gross capital formation, the revision arising mainly out of the necessity of obtaining information on capital expenditures by type of end-user of the capital facilities created. In the same year the DBS published its most comprehensive study of the Canadian national accounts, also covering the period 1926-1950. This study incorporated the revised series of capital formation into the national accounts, abandoning as obsolete, as had the Department of Trade and Commerce, the earlier estimates of capital formation.

The main reason why Buckley appears to prefer to use the obsolete series for the period 1926-1940 is his belief that certain biases are inherent in the more recent estimates of expenditures on new machinery and equipment which were based on a sample of 358 manufacturing firms. This sample consisted of corporation income tax returns submitted to the Canadian Department of $\mathrm{Na}$ tional Revenue for the period 1926-1946. The sample of companies, which accounted for 38 per cent of the gross value of production by manufacturing industries in 1946, was chosen with great care. Special allowances were made for old companies discontinuing their operations and new companies starting in business. It took about three years to obtain information. which covered quite a number of other balance sheet items besides data on capital expenditures. Some of the reasons it took so long were the emphasis put on obtaining a clear understanding of the accounting definitions used by reporting firms, the need to make adjustments where inconsistencies appeared, and, among other things, the need to take full account of mergers that were taking place during this period. Incidentally the corporation sample was used to improve the official estimates contained in the national accounts in a number of fields. These new series are available in the revised estimates of the DBS published since 1951, and they include depreciation allowances, inventory change, etc. 
I have no doubt that those who were in charge of the corporation sample survey would be the first to admit that, even with all the care they applied to selecting the sample and obtaining the required corporation data, and with all the testing and checking they did, the resulting estimates still contain a number of imperfections. I believe they would even go further and say that many of the estimates of capital expenditure for particular industries may be subject to a larger margin of error than estimates for a large sector such as manufacturing, and that the margin of error would be even smaller for gross capital formation in aggregate. In fact Buckley seems to share this point of view when he points out that the bias in the machinery and equipment estimates he believes to exist in one particular industry, the food and beverage industry, may exist, to a smaller degree, in other industries.

Before turning to some of the reasons that led to a change from a commodity flow to an end-user approach, where possible, in arriving at new estimates of capital formation in Canada, two other points may be worth considering.

First, before accepting fully the results of the single test relating to the food and beverage industry which Buckley has made and then used to generalize on the estimates of capital formation as a whole, it may be well to examine the meaningfulness of some of the data used as test material. For example Buckley uses figures on capital employed in the "animal and vegetable products" groups, a somewhat different classification from that used in the investment estimates, and compares it with total capital employed in all manufacturing industries as given in the annual censuses undertaken by the DBS. But the DBS has discontinued collecting these data since 1943 because it found that the reporting firms used such a variety of concepts of capital that the resulting aggregate figures were of doubtful value.

Secondly it might be of interest to examine the United States experience, to know what the Securities and Exchange Commission thinks of the corporation statistics they obtain from the records of reporting companies, and what experiences the United States Department of Commerce has had in adapting the information obtained from corporation samples in order to improve and obtain greater detail on some of the components shown in the United States national accounts.

However, the basic question before us is this: Even if there are some biasés in capital expenditures reported by business corporations, are these in aggregate likely to be greater or smaller 
than those inherent in estimates of capital formation based on commodity flow data?

There were in the main two reasons for switching from the commodity flow technique used in P.I.C.F. to the end-user approach employed in P.P.I.: (1) the need to obtain an industrial breakdown of capital expenditures, and (2) the belief that the end-user approach would avoid several biases inherent in the use of the flow data and that any biases still inherent in the new aggregate estimates of capital formation would be of lesser significance than those that were known to exist in the old estimates.

There are three biases affecting the estimates based on commodity flow data which may explain some of the divergencies that exist between the two series: (1) the lack of adequate data to allow for annual inventory change in commodity flows, (2) the inability to determine with assurance the end use of many of the commodity flows, and (3) the inadequacy of the commodity data to allow a satisfactory distinction between new investment and repair and maintenance expenditures.

To illustrate the possible existence of such biases in the commodity flow data-without denying that there may also be some biases in the end-use data, as Buckley suggests-two charts are attached. In Chart $l$ the series on new investment in machinery and equipment, as per P.I.C.F., is compared with that given in P.P.I., and the totals for new machinery and equipment and repair and maintenance expenditures are shown in Chart 2.

Estimates of new machinery and equipment based on commodity flow data rely on production and export and import statistics. Production plus imports minus exports yields domestic disappearance, which in turn is equal to domestic consumption and change in inventories. Since no adequate data are available on changes in inventories, the machinery and equipment estimates in the P.I.C.F. series are in substance based on domestic disappearance estimates. One would assume that, because no or only inadequate allowance could be made for inventory changes, the resulting series would show an upward bias in periods of rising economic activity and a downward bias in periods of declining levels of new investment, income, and output. For expanding demand for machinery and equipment is usually accompanied by rising output of these items, and a build-up of inventory becomes necessary to cater to expanding business. On the other hand when demand

'Private and Public Investment in Canada, 1926-1951, Ottawa, Dept. of Trade and Commerce, 1951 (P.P.I.). 
CAPITAL FORMATION IN CANADA

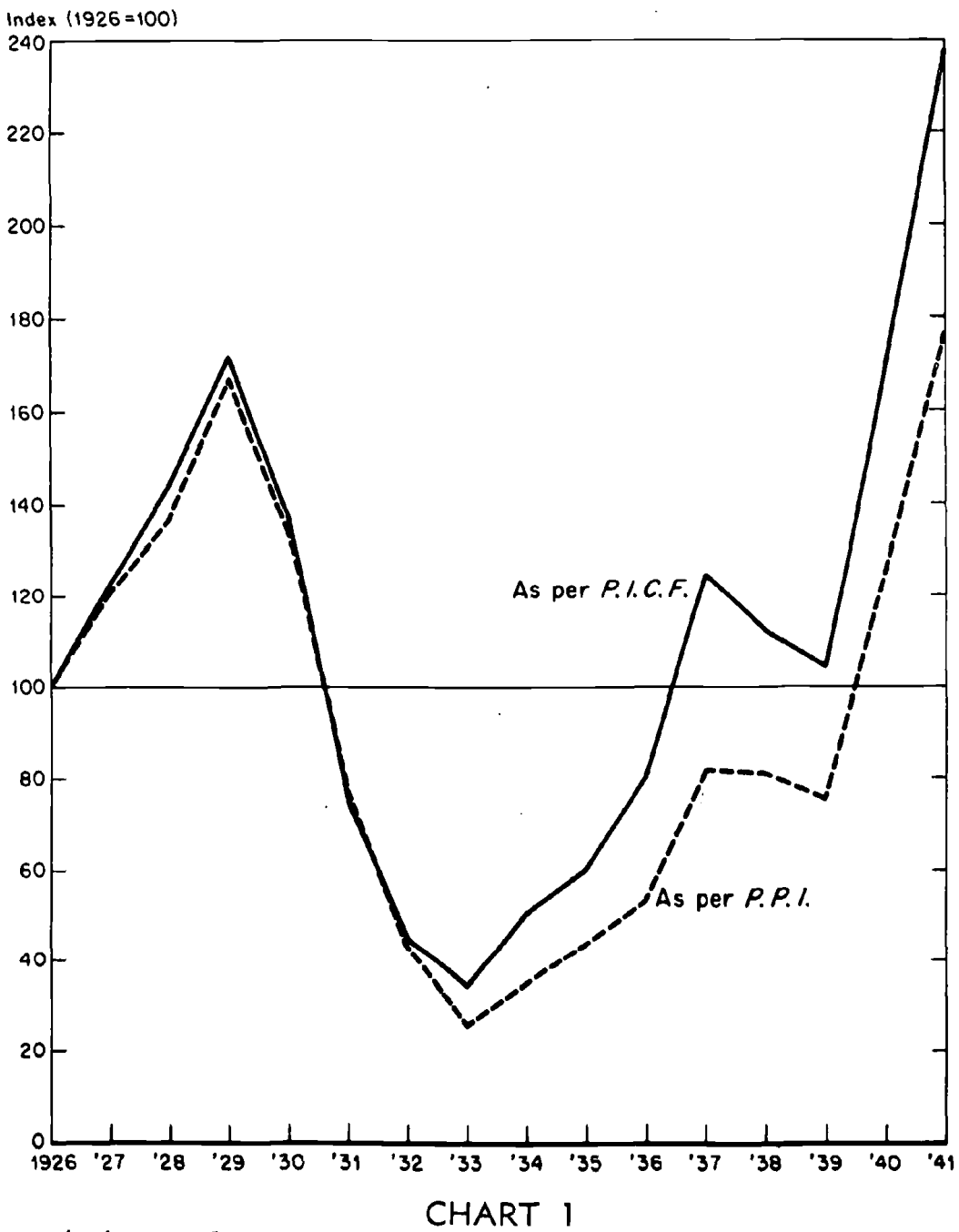

Indexes of Investment in New Machinery and Equipment, as per P.I.C.F. and P.P.I., Canada, 1926-1941 


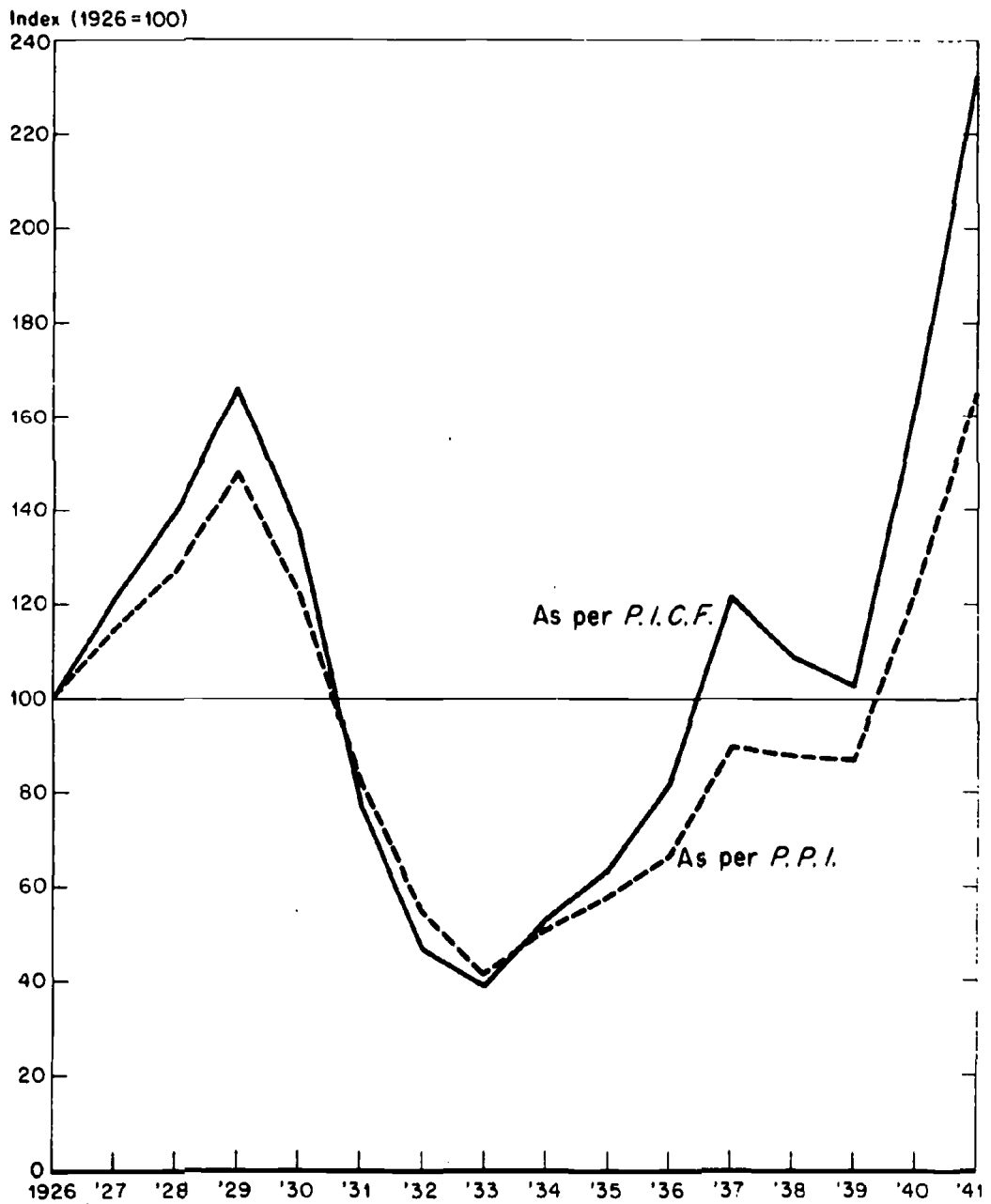

CHART 2

Indexes of Investment in New Machinery and Equipment and Repair and Maintenance Expenditures, as per P.I.C.F. and P.P.I., Canada, 1926-1941 


\section{CAPITAL FORMATION IN CANADA}

for machinery and equipment drops, output may decline even more than demand as businessmen endeavor to reduce their inventory holdings.

As Chart 1 shows, new machinery and equipment estimates, as per P.I.C.F., rose more rapidly than machinery and equipment as per P.P.I. from 1926 to 1929 and from 1933 to 1941. As for the downturn from 1929 to 1933 , both series show a very similar trend, with the P.P.I. series showing a shade more rapid decline. But this is due mainly to another inadequacy of the P.l.C.F. series, the assumption of a constant ratio between new machinery and equipment purchases and maintenance and repair expenditures. As confirmed by business experience in Canada and by studies in other countries, expenditures on new equipment decline more rapidly in a depression than expenditures on repair and maintenance. Thus in effect the ratio is a changing one rather than a constant one as assumed in the P.l.C.F. study. A glance at Chart 2, which removes that bias of the constant ratio and compares totals of new investment in machinery and equipment and repair and maintenance expenditures as per P.I.C.F. and P.P.I., shows that in the former series the decline from 1929 to 1933 was more rapid than in the latter.

Another reason for the difference in the two series is the difficulty in determining with any degree of accuracy the actual end use of various items obtained from commodity flow data. For example about 10 per cent of industrial machinery in the P.l.C.F. estimates is made up of electric motors. There is evidence to suggest that through the 1930's a continuously increasing proportion of these were going into consumers' durables, e.g. in 1929 some 4,700 electric refrigerators were produced in Canada. Production of these items rose consistently through the 1930's, reaching 52,900 in 1938 .

Another bias in the commodity flow data was introduced with the outbreak of World War II. It became very difficult to determine the end use of many equipment items which were usable for both military and industrial purposes. The bias would be more moderate in 1939 and 1940 but would be of greater importance in 1941 when Canada's military efforts were on a much larger scale. It is, in fact, in 1941 that the two series show the greatest divergency as both Charts 1 and 2 indicate. Over the period as a whole the two series show a closer similarity of trend if investment in new machinery and equipment and repair and maintenance expenditures are considered together, as in Chart 2, rather than when new in- 
vestment in machinery and equipment is considered by itself, as in Chart 1.

In pointing to some of the shortcomings of the estimates based on commodity flows, there is no suggestion that these do not have important uses in economic analysis. The suggestion here is only that, where a country is fortunate enough, as Canada is in the case of investment estimates, to have both a set of estimates based on commodity flow data and one based on end-user data, the two series can be used to check each other, with both sets of data useful for specified analytical purposes. Perhaps the most encouraging point is that notwithstanding the possible existence of biases in both series the resulting aggregate estimates follow very similar trends, particularly as indicated in Chart 2.

At the end of his paper Buckley indicates that it would be useful to have information available on capital formation going back beyond 1900 . While a great deal of research has to be done to make systematic economic analysis of Canadian economic development possible for this earlier period, it might be of interest to note that some work has been done recently in this field. Information on investment in construction and new machinery and equipment going back to 1870 together with other components of gross national expenditure for selected years, and annual estimates of gross national expenditure from 1867 to date, are shown in a study entitled "Canada's Economic Development, 1867-1953, with Special Reference to Changes in the Country's National Product and National Wealth,"“

\section{REPLY BY MR. BUCKLEY}

As a result of Penelope Hartland's comments I must acknowledge that differences of negligible amounts in the estimates of foreign investment from 1926 to 1941 in P.l.C.F. and in the national accounts are the result of an important difference in the concept of foreign investment and not, as $I$ had assumed, of minor revisions in balance of payments statistics. The current official estimates exclude migrants' capital and inheritances; P.I.C.F. and the 19001930 estimates do not. Hartland pointed out that the amounts involved are far from negligible in the earlier period and that a vari-

\footnotetext{
'Prepared by the author for the Third Conference of the International Association for Research in Income and Wealth, Castelgandolfo, Italy, September 1-6, 1953.
} 


\section{CAPITAL FORMATION IN CANADA}

ant excluding migrants' capital would be more appropriate for some purposes. I regret that I do not have estimates of the relevant transfers for the period 1914-1925 and so cannot provide the suggested variant at this time.

My paper is not, as 0 . J. Firestone states, largely based on my doctoral thesis; only the 1900-1.930 estimates are from that source. The descriptions of the sources and methods of the 1900-1930 estimates have not been included because they have been published elsewhere.

The reliability of the P.I.C.F. estimates of investment in machinery and equipment may be questioned on several grounds, three of which are cited by Firestone. However, these limitations of the P.I.C.F. estimates will not, I think, support the conclusions he bases upon them. His discussion of the effect of the P.I.C.F. procedure with respect to machinery and equipment and repair parts is based upon a false premiss, what he refers to as "...another inadequacy of the P.I.C.F. series, the assumption of a constant ratio between new machinery and equipment purchases and maintenance and repair expenditures." That this assumption was not made by the authors of P.I.C.F. is evident in Firestone's charts. The several procedures and sources actually used are described in P.I.C.F., pages 106-108. Another conclusion advanced by Firestone is derived from the fact that "no or only inadequate allowance could be made for inventory changes" in the P.I.C.F. series. In his argument he assumes an inventory pattern of the shape required by his conclusion. Apart from this, what one could reasonably assume from the fact that that "no or only inadequate allowance" was made would surely vary depending upon whether no inventory allowance was made or an inadequate allowance, which means, in this particular instance, an allowance made on the basis of partial data and involving possibilities of error in direction as well as magnitude.

Finally it seems to me that Firestone overlooks the extent of the difference between the new and the old estimates of investment in machinery and equipment when he states that "both sets of data [are] useful for specified analytical purposes" and that they "follow very similar trends." I disagree because the two series yield different answers to fundamental questions about the pattern of economic development in Canada. For example if one accepts the P.P.I. estimates, then one must believe "that the postwar peak of manufacturing investment only approached but never reached the high volume level of 1929" (P.P.I., page 20), and 


\section{CAPITAL FORMATION IN CANADA}

that the "import content of machinery and equipment purchases... was about one-fifth in 1929 and was up to about one-third in 1950 ..." (ibid., page 22). On these questions the P.P.I. series refutes not only the contrary evidence of P.I.C.F. but also common sense impressions created by the available statistics of manufacturing and trade. 